Running head: A META-STUDY OF MT DEVELOPMENT

\title{
A Meta-study of Qualitative Research on Mental Toughness Development
}

aDavid R. Anthony*, b Daniel F. Gucciardi, and a Sandy Gordon

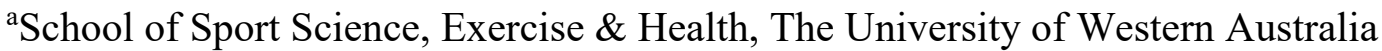

${ }^{\mathrm{b}}$ School of Physiotherapy and Exercise Science, Curtin University

\section{Authors' Notes}

Daniel F. Gucciardi is currently supported by a Curtin Research Fellowship.

*Address correspondence to David R. Anthony, School of Sport Science, Exercise \& Health, The University of Western Australia, M408, 35 Stirling Hwy, Crawley, WA, Australia, 6009. Email: dranthony311@gmail.com

Accepted for publication in International Review of Sport and Exercise Psychology on January $18^{\text {th }} 2016$ 


\begin{abstract}
Mental Toughness (MT) is considered a necessary ingredient for high level performance. Unsurprisingly, scholarly interest in the development of mental toughness has increased over the past decade, with much of this work informed by qualitative designs. No study to date has systematically reviewed and integrated this body of qualitative research on MT development. The primary purpose of this study was to create an integrated theoretical framework that incorporates extant MT development research in sport and performance settings. Three subsequent aims were to (i) systematically review and evaluate the qualitative literature regarding key developmental factors and processes for MT; (ii) synthesise knowledge of key developmental factors and processes for MT; and (iii) generate an integrated framework that can inform future research and advancement in theory with regard to MT development. Following a systematic search of online journals, search engines, and databases, 10 papers met the criteria for inclusion and were retained. These studies served as the primary data for meta-data, meta-method, and meta-theory analyses, which were integrated using a meta-synthesis approach. Four key themes were identified from the existing qualitative evidence: personal characteristics, interactions with environment, progressive development, and breadth of experience. These unique themes were integrated with existing theory to propose a Bioecological Model of MT Development that encompasses interdependent interactions among the person, proximal processes, context, and time. We describe how this model can be used as a heuristic for research and practice, and underscore the importance of methodological diversity for future work on the development of MT.
\end{abstract}

Keywords: Athlete, coaching, mentally tough, performer, person-situation interactions, talent Word count: 8419 


\section{A Meta-Study of Qualitative Research on Mental Toughness Development}

It is widely recognised that the development of talent is a complex process that requires multidisciplinary contributions from key areas of sport science, such as physiology, biomechanics, motor learning and psychology (Gulbin, Croser, Morley, \& Weissensteiner, 2013; Vaeyens, Lenoir, Williams, \& Philippaerts, 2008). Over the past decade, researchers interested in the psychological factors associated with the attainment and sustainment of peak performance have approached this task through the lens of mental toughness (MT). Recently defined as "a personal capacity to deliver high performance on a regular basis despite varying degrees of situational demands" (Gucciardi \& Hanton, in press, p. x), MT is considered by many to be central to sport performance (e.g., Gucciardi, Hanton, Gordon, Mallett, \& Temby, 2015; Hardy, Bell, \& Beattie, 2014). Unsurprisingly, there have been concerted efforts towards delineating an understanding of the sources of influence and key mechanisms of MT development within sport. Whether these efforts have involved qualitative or quantitative research, key conclusions from past work suggest that MT development is a complex endeavour that involves multiple mechanisms (e.g., exposure to challenging or tough situations) and sources of influence (e.g., coaches, teammates) (Connaughton, Thelwell, \& Hanton, 2011).

There are several published narrative reviews of the MT literature that have focused on conceptual features (e.g., Connaughton, Hanton, Jones, \& Wadey, 2008; Crust, 2007), measurement considerations (e.g., Gucciardi, Mallett, Hanrahan, \& Gordon, 2011) or its development (e.g., Connaughton et al., 2011). Although narrative reviews can be informative and cover a broad range of important issues within a topic because they are often conducted by experts in the field (Collins \& Fauser, 2005), they typically involve informal and unsystematic approaches to the identification and integration of primary data, producing mainly descriptive summaries of bodies of work (Noblit \& Hare, 1988). In contrast, 
systematic approaches that involve detailed plans of methodological procedures (e.g., search strategy, inclusion/exclusion criteria) can reduce potential bias by producing a comprehensive integration, appraisal and synthesis of all key studies on a specific topic (Paterson, Thorne, Canam, \& Jillings, 2001) and therefore enhanced transparency in the research process. The ongoing preference in both MT and MT development research has been to employ similar processes to previous research, such as the same theoretical bases (e.g., Kelly's (1955/1991) personal construct psychology), or research designs (e.g., retrospective semi-structured interviews with experienced informants). The common result is support for what was already known with limited advancements in the conceptual understanding of what it is stakeholders such as athletes, coaches, and/or sports administrators should actually do to develop MT or, more specifically, when they should do it. Therefore, as a necessary first step, enhanced clarity regarding both the developmental factors (e.g., who, when, and where) and processes (e.g., what and how) of MT through systematic integration has the potential to lead to increased confidence and receptiveness to interventions among these stakeholders (e.g., Campbell et al., 2000). Currently, there are only two published controlled intervention studies (i.e., Bell, Hardy, \& Beattie, 2013; Gucciardi, Gordon, \& Dimmock, 2009), and another intervention study with no control group (i.e., Sheard \& Golby, 2006). With the exception of Bell et al. (2013), whose work was grounded in reinforcement sensitivity theory (Gray \& McNaughton, 2000), intervention research to date has been atheoretical; thus, there is a need for theory to guide future intervention work (e.g., Mahoney, Gucciardi, Mallett, \& Ntoumanis, 2014).

With much of the available research on MT development informed by qualitative methods (Connaughton et al., 2011), there is a need to synthesise the findings of this body of work. One approach is through a systematic integration of the knowledge regarding the antecedents and developmental themes of MT, which may also provide clarity as to what MT 
is and what it is not, as well as those key features evident in mentally tough athletes and performers (henceforth referred to as performers). A meta-study (Paterson et al., 2001) is one such process that enables the synthesis of qualitative research, which includes a systematic approach to the collation of studies, a critique of methodological approaches, and a synthesis of findings. Subsequently, a synthesis of qualitative research appears warranted as a means by which to clarify substantive considerations of key sources of influence or developmental processes, inform the development and evaluation of future intervention programs, and increase stakeholders' desire to invest resources into these programs.

To our knowledge, there has been no systematic review of qualitative research on MT development. The primary purpose of this study was to create an integrated theoretical framework that incorporates extant qualitative MT development research. Using a metastudy approach to achieve this goal, the three aims were to (i) systematically review and evaluate the qualitative literature regarding key developmental factors and processes for MT in sport and performance settings; (ii) synthesise knowledge of key developmental factors and processes for MT in sport and performance settings; and (iii) generate an integrated framework that can inform future research and advancement in theory with regard to MT development in sport and performance settings.

\section{Methods}

A meta-study "involves a systematic approach to collecting and analysing qualitative research findings" (Tamminen \& Holt, 2010, p. 1564) using interpretation rather than reduction of data (Sandelowski \& Barroso, 2003). This systematic approach consists of four components (Paterson et al., 2001): meta-method analysis, meta-data analysis, meta-theory analysis, and meta-synthesis. The first three components (method, data, and theory analysis) often take place concurrently; the meta-synthesis is presented as the outcome of a meta-study. Two primary objectives of a meta-study are to identify unanimity, and explore 
inconsistencies in existing literature, which together contribute to the qualification of research for concept development. A PRISMA checklist (Moher, Liberati, Tetzlaff, Altman, \& The PRISMA Group, 2009) was also completed for this review, and is available online as supplementary material.

\section{Search Methods}

A search was conducted of online journals, search engines and databases to retrieve relevant articles. The search protocol in each case was set to search titles, abstracts, and keywords using the terms "mental toughness" and "mentally tough", with no limitations in terms of the date range, with the final search conducted December 2014. The search platforms used were Web of Science, Scopus, Sport Discus, OvidSP, and Google Scholar. Articles were not retained for further analysis during this process if they were identified as non-scholarly periodicals (e.g., popular press or newspaper articles), or duplicates of articles that had already been collected. Both backward (i.e., scanning reference lists of included articles) and forward search strategies (i.e., work that has cited included articles) were then conducted to check all articles fitting the criteria were collected. A male librarian with more than 10 years' experience using search databases was also consulted during the early stages to ensure all articles that met the criteria were identified.

Exclusion and inclusion criteria. Based on guidelines for the synthesis of qualitative data (Sandelowski, Docherty, \& Emden, 1997), articles were excluded if one of the following criteria was evident: (i) participants took part in an intervention and asked to report their perspectives of the content of the program, rather than their broader views of MT development; (ii) involved only quantitative methods (i.e., numbers were the focus of the analysis, with no exploration of peoples' perceptions of MT development); (iii) drew from a non-sport/performance setting; (iv) involved analysis of historical/archival data (or review articles); (v) was not published in a peer-reviewed journal (i.e., conference presentation or 
book chapter); and (vi) if the study identified MT development as an important consideration in the findings, rather than being specified a priori as a research aim. Articles were included if they employed research methods that allowed for the exploration of participants' perceptions of MT development (i.e., one-on-one interviews, focus groups, open-ended surveys, or case study observations). This step was an important part of this review in an attempt to challenge the ongoing conjecture regarding what constitutes MT in the field, and look at the "raw data" provided by qualitative research, as opposed to the modified categories offered by quantitative research. A flow diagram of the search and retrieval strategies is depicted in Figure 1.

\section{Data Abstraction and Management}

Following meta-study guidelines (e.g., Paterson et al., 2001), key features of research articles that were retained were entered into a spreadsheet (e.g., sample characteristics, data analysis). This template was constructed by reviewing each article in its entirety during which the relevant information was entered into the corresponding columns (see Tables 1 and 2 for abbreviated forms). A full copy of the data extraction template is available online as supplementary material, or alternatively from the first author upon request.

\section{Meta-Method Analysis}

A meta-method analysis involves a review and evaluation of the research designs of each primary study to identify how the specific research methodologies have been applied, and the effects they have on the findings and outcomes, as well as an assessment of the collective methodological patterns across the retained MT development literature (Paterson et al., 2001). Two steps formed the basis of this meta-method analysis: (i) a review of each of the retained article's theoretical basis, sampling methods, sample characteristics, as well as methods for data collection and data analysis; and (ii) an evaluation against a 10-item Qualitative Research Checklist (CASP, 2014), which is a tool used to assist with systematic 
appraisal of qualitative research in terms of the validity (e.g., Is there a clear statement of the research aims?), whether the results are important (e.g., Were participants recruited appropriately?), and how useful it is to the field (e.g., Are the findings clearly stated?). The findings from these analyses are reported in Tables 1 and 3, with further detail provided in the results section.

\section{Meta-Data Analysis}

A meta-data analysis involves an examination of the findings from each primary research report (Paterson et al., 2001) to provide insight into the common concept being studied across a group of reports (Tamminen \& Holt, 2010). Therefore, themes from each article were compared and contrasted against others in an attempt to synthesise existing knowledge. We used an adaptation of Noblit and Hare's (1988) seven-step metaethnography: (i) getting started; (ii) deciding what is relevant to the initial interest; (iii) reading the studies; (iv) determining how the studies are related; (v) translating the studies into one another; (vi) synthesising translations; and (vii) expressing the synthesis. Although our synthesis did not focus specifically on metaphors, this method can be applied when reviewing related themes and concepts among a collection of similar qualitative research (Britten et al., 2002; Paterson et al., 2001).

Steps 1-3 of the meta-ethnography were applied as a part of the literature search and selection process. Subsequently, the findings from each of the retained studies, which were treated as raw data in the analysis, were reviewed to identify the relations between them (step 4). These findings were then coded and grouped according to their similarities (e.g., participant roles, sport-specific versus sport-general samples). As a result, the raw data was initially collated according to the participant role, with a sub-theme being the performance context (see Table 2). The information in these categories was then compared and contrasted against the others to explore the degree of dis/similarity in the data when collated in this way. 
The next step was to review the studies to see how they might translate into one another (Step 5; Noblit \& Hare, 1988). There were a number of similarities identified when comparing key phrases, themes and concepts within primary studies against the same factors across each of the other reports. For example, phrases such as "enhancing psychological skills" (Butt, Weinberg, \& Culp, 2010) and "psychological skills training” (Thelwell, Such, Weston, Such, \& Greenlees, 2010) relate to the development of personal characteristics, subsequently offering an opportunity to synthesise these translations (Step 6). For the final synthesis (Step 7), these factors were collapsed into descriptive thematic categories, such as "personal characteristics". This process was used to combine and analyse other similar concepts within the retained MT development literature.

\section{Meta-Theory Analysis}

A meta-theory analysis refers to the critical analysis of extant theory to develop a unified theoretical understanding of the phenomenon (Paterson et al., 2001). Theoretically informed studies are important for science since they can inform a priori expectations regarding results, provide guidance in terms of data collection methods, and offer an organising framework for data interpretation and synthesis. Central to this aspect of a metastudy is an examination of whether, and in what way, such theoretical underpinnings influence a body of work (Paterson et al., 2001). According to Ritzer (1992), there are three reasons for meta-theorizing: (i) to attain a greater understanding of the underlying structure of existing theory; (ii) as a precursor to the development of new theory; and (iii) to provide a comprehensive framework that helps explain some or all of the existing theories. The majority of the research retained for the current synthesis is based on Jones, Hanton, and Connaughton's (2002) seminal framework of key personal attributes of MT individuals, which was guided by Kelly’s (1955/1991) personal construct psychology. Subsequently, the 
primary focus during this stage was to compare the current theoretical basis of MT development with other existing theories of development to progress our understanding.

\section{Meta-Synthesis}

The final stage involves a meta-synthesis of the data, methods and theories from research reports that have explored similar constructs in an attempt to generate an integrative theory or framework of an area of research (Paterson et al., 2001). Therefore, the specific purpose of the current meta-synthesis was to develop an explanatory theory or model that might explain the findings of a collection of qualitative studies (Walsh \& Downe, 2005), with a view to provide a foundation for future research. Described as "a dynamic and iterative process of thinking, interpreting, creating, theorising, and reflecting" (Paterson et al., 2001, p. 112), an inductive approach was adopted initially that provided an opportunity to identify common themes from the retained research. This process was conducted by the first author, and regularly discussed, revised, and refined through consultations with the second and third authors.

\section{Results}

The results from the search strategy are shown in Figure 1. Following the removal of duplicates, the search resulted in 206 peer-reviewed publications, which was reduced to 10 articles once the exclusion criteria were applied. A summary of the key features of the primary research reports is detailed in Table 1. Several studies were conducted in specific countries, including North America $(n=3)$, United Kingdom $(n=2)$, and Australia $(n=2)$. The remaining studies involved a mix of between two and four countries $(n=2)$, with one study's location not identified. Sample sizes ranged from 7 to 18 , with participants recruited predominantly via purposive sampling, that is, selected because they have the potential to advance our understanding of MT development (e.g., length of time working with elite performers, exposure to elite level competition, level of success etc.). The qualitative data 
from the 10 studies represents a total of 115 participants, which includes performers $(n=69)$, coaching staff ( $n=39)$, and support staff $(n=7)$. Age range (when reported) and levels of experience varied from high school 'top' performers (aged 13-17 years), to athletes (from 15 years of age), support staff and coaches (from 25 years old) with international level success.

\section{Evaluation of the Methods and Methodological Themes}

A summary of the methods of each study is provided in Table 1. The assessment of each study against the CASP checklist is provided in Table 3. All articles were clear in their research aims and the selection of a qualitative methodology in each instance appeared appropriate. Nevertheless, two studies (i.e., Cook et al., 2014; Weinberg et al., 2011) provided limited information regarding their choice of methods and research design, thereby limiting the opportunities for the studies to be replicated by other researchers. Specific detail regarding these factors, as well as other inconsistencies across the retained studies is provided in the subsequent sections.

Data collection. Although semi-structured interviews were the common approach, there appeared to be little consistency regarding the information that was provided to the participants prior to, or during the interview. For example, in their research with gymnasts, Thelwell et al. (2010) provided Jones and colleagues' (2002) definition of MT and the key attributes to each participant prior to the interview. In contrast, Butt et al. (2010) contacted participants via phone prior to the interview to briefly discuss MT, asking whether the participant considered themselves MT and in what situations they demonstrated it. The participants were then engaged in a face-to-face interview, with no information regarding whether additional information on MT was provided during these discussions. Bull, Shambrook, James, and Brooks (2005) provided participants with a general information package on reasons for the interview, but did not include any specific information relating to the conceptualisation of MT. In some cases, it was not clear whether or not additional 
information was provided to participants prior to interviews (e.g., Cook, Crust, Littlewood, Nesti, \& Allen-Collinson, 2014; Weinberg, Butt, \& Culp, 2011).

Sampling method and characteristics. Although eight of the ten studies utilised a purposive sample (see Table 1), the experience levels of participants across the studies varied. Specifically, there were inconsistencies regarding the identification of who is mentally tough, what level of performance must be reached, and how many years' experience is required for a participant to be considered a valid source of information on MT development. In their research with coaches, for example, Weinberg et al. (2011) specified a minimum of 10 years coaching experience at NCAA Division 1 level, whereas Gucciardi, Gordon, Dimmock, and Mallett's (2009) sample had a minimum level of experience either as a head coach or assistant coach at the elite level, with no specific time period identified. Other examples refer to "full international honours" (Thelwell et al., 2010) or a minimum of one year of competition experience at NCAA Division 1 level (Butt et al., 2010). There were a number of other similarities regarding the methods employed across the retained studies. For example, participants who shared their perspectives on what MT is were re-interviewed to provide their perceptions on its development (e.g., Connaughton, Hanton, \& Jones, 2010; Connaughton, Wadey, Hanton, \& Jones, 2008; Gucciardi, Gordon, Dimmock, et al., 2009).

Data Analysis. There was a preference for content analysis (inductive and deductive) with analyst triangulation involving two or more authors (e.g., Butt et al., 2010; Connaughton et al., 2008; Thelwell et al., 2010). Such an approach is regularly identified as appropriate when dealing with qualitative data in the concept formulation stage (Miles \& Huberman, 1994; Patton, 2002).

\section{Evaluation of the Theoretical Underpinnings}

Jones and colleagues (2002) were among the first to identify and explore performers' perceptions of MT, using Kelly’s (1955/1991) personal construct psychology (PCP) as a 
guiding framework. From a PCP perspective, people are considered active agents in the construction of knowledge through their interpretations of reality. Although not explicitly mentioned in the primary studies, this constructivist perspective was an inherent feature of the retained articles in this meta-study, with the researchers exploring MT development using participants that were believed to have lived it (Gergen, 2009). The definition of MT and key attributes proposed by Jones and colleagues' $(2002 ; 2007)$ was the predominant theoretical framework cited as the starting point across the majority of the retained studies. However, in some cases, the level of detail was not explicit; for example, Cook et al. (2014) reported that they drew on previous MT research findings and recommendations, as well as their own theoretical interests, whereas Weinberg et al. (2011) cited existing MT literature for their framework with little detail on guiding features of this knowledge base.

\section{Similarities and Differences in Primary Research Findings}

A summary of the main themes from each study and their relations with existing research is detailed in Table 2. MT development was described in six of the 10 studies as a multidimensional process where unique attributes or subcomponents are developed using different strategies (Bull et al., 2005; Connaughton et al., 2010; Connaughton et al., 2008; Cook et al., 2014; Gucciardi, Gordon, Dimmock, et al., 2009; Mahoney, Gucciardi, et al., 2014). The remaining four studies focussed on MT development as a unidimensional construct, reporting concepts that may develop MT generally, as opposed to methods to develop any specific component or attribute of MT. Another key similarity across the extant research into MT development was the notion that it is an almost lifelong process beginning in early adolescence. Connaughton et al. (2010) proposed that there are three distinct career phases regarding the developmental process, as well as a maintenance phase; Gucciardi, Gordon, Dimmock, et al. (2009) identified that experienced coaches viewed parental influences in early adolescence as important in developing a 'generalised form' of MT; and 
Weinberg et al. (2011) reported that effective MT development in college athletes required some level of MT that had been developed during adolescence.

The primary theme to be drawn from relevant MT development research is that it is considered a multidimensional process consisting of a number of inter-related mechanisms (cf. Connaughton et al., 2011), providing an opportunity to group similar concepts together during the meta-data analysis. As a result, four key categories were identified across the retained studies: (i) personal characteristics; (ii) interactions within environment; (iii) progressive development; and (iv) breadth of experience.

Personal characteristics. This category encompasses malleable personal skills or resources that an individual might implement at a given time across a range of different contexts, often a result of learning from previous experiences. Relevant factors from the retained studies included "tough character, tough attitudes and tough thinking" (Bull et al., 2005), "heightened awareness" (Mahoney, Gucciardi, et al., 2014), "cognitive strategies" (Driska, Kamphoff, \& Armentrout, 2012), and "reflective practice" (Connaughton et al., 2010). Considering the influence of significant others on one's skill development, particularly during adolescence, it is important to also include factors such as the development of "resourcefulness, via a challenging but supportive learning environment" (Cook et al., 2014). This finding highlights the importance of the association between the adaptive development of one's personal characteristics and the type of support available, such as a supportive learning environment.

Interactions within environment. This second category relates to how the interactions between performers and various stakeholders within the environment might affect their ability to develop. This category differs from personal characteristics in that it is not about the specific skills or resources performers could employ, such as reflective practice or tough thinking, but more about how different environmental factors may facilitate or 
impede MT development. One of the most pertinent examples from previous research was given by Connaughton et al. (2008), identifying that "encouragement from significant others who also act as a resource of knowledge and inspiration" is important for MT development. This factor not only highlights that the interactions between the performer and significant others within the performer's environment are important, but also identifies that these stakeholders should also be a resource of knowledge and inspiration within the performer's environment. Other factors such as the "coach-athlete relationship" (Gucciardi, Gordon, Dimmock, et al., 2009), "[relationships with] coaches, parents, and teammates respectively" (Butt et al., 2010), and "access to an understanding social support network" (Connaughton et al., 2010) are examples of the importance of the person-environment interaction identified in previous research. Similarly, a performer exposed to a supportive training and family environment (e.g., Thelwell et al., 2010), or an environment where "the coach developed a motivational climate that fostered mental toughness" (Driska et al., 2012) emphasises the importance of how relationships within environments contribute to MT development.

Progressive development. Less about specific skills and the person-environment interactions, the third category relates to the importance of ongoing opportunities for growth or development within the environment throughout one's career. Often we read about athletes changing coaches or teams after a long-term coach-athlete relationship for a fresh start, or as a result of a moving into a new stage of life, and these events can be attributed to factors relating to this theme. For ongoing performance improvement, contextual factors such as "[a] positive but tough practice environment" (Butt et al., 2010), "a motivational climate that is challenging" (Connaughton et al., 2008), a facilitative coaching philosophy and training environment (Gucciardi, Gordon, Dimmock, et al., 2009), and opportunities for skill mastery, success in training, and international competitive experience (Connaughton et al., 2010) are necessary to facilitate such growth. Furthermore, personal factors such as 
“independence, via a challenging but supportive learning environment” (Cook et al., 2014) highlights the importance of not only a level of autonomy (via independence), but a learning environment that fosters independence while providing the necessary support.

Breadth of experience. The fourth theme is used to categorise those significant events, or critical incidents, that occur throughout one's career that are necessary for MT development, as well as the importance of diverse experiences over time to facilitate adaptive and positive growth. Importantly, these events are considered most beneficial when a performer is operating within a supportive environment (e.g., adaptive relationship with coach/family), has developed the necessary characteristics (e.g., can employ psychological skills such as reflective practice), and has the requisite level of preparation (e.g., from a positive but tough practice environment). Factors such as "coping with pressure" (Bull et al., 2005), critical incidents (e.g., Connaughton et al., 2010; Connaughton et al., 2008; Mahoney, Gucciardi, et al., 2014), and "overcame hardship in the sport" (Driska et al., 2012), can be applied to this fourth theme due to the emphasis on a performer not just experiencing, but also adapting following significant events. Another factor that is relevant to this category was "negative experiences and influences (to impede the process)" (Gucciardi, Gordon, Dimmock, et al., 2009), which related to situations or environments where there are limited opportunities for adaptive and positive growth. Although these factors might initially promote thoughts of adversity as being central to growth, it is important to highlight that examples of more positive events were also given, such as "international competitive experience" (Connaughton et al., 2010), and a "rewarding and enjoyable climate" (Connaughton et al., 2008).

\section{An Integrated Framework of MT Development}

Individually, each of the aforementioned four key themes represents a new interpretation of the shared findings from the existing body of qualitative evidence on MT 
development. Revisiting these core themes in conjunction with the demographic, historical and sociocultural factors identified in the analyses of the methods and guiding theory in this past work facilitated the proposal of an integrative conceptual framework of MT development. As Mahoney, Gucciardi, et al. (2014) initially identified in their MT development research, there are similarities between the properties of Bronfenbrenner and Morris's (2006) Bioecological Model of Human Development and the processes identified as important to MT development. This model encompasses four components of process-personcontext-time (PPCT; Bronfenbrenner \& Morris, 2006) that resemble the themes identified in our meta-data analysis. Thus, this model offers a well-developed and empirically supported framework that can be used to synthesise past work on MT development, and extends on Mahoney and colleagues' work by taking a systematic approach to reviewing all past qualitative MT development research. The proposed Bioecological Model of Mental Toughness Development is illustrated in Figure 2.

The Bioecological model represents a broad, robust theoretical foundation where development is defined as "the phenomenon of continuity and change in the biopsychological characteristics of human beings" (Bronfenbrenner \& Morris, 2006, p. 793). A synthesis of the current findings according to the four components of the model, being process, person, context, and time, is detailed in Table 4. The first of these components, aligning with the progressive development category identified earlier, serves as a foundation for explaining development and is labelled proximal processes; that is, the continually evolving performerenvironment exchanges that offer ongoing opportunities for development (Bronfenbrenner \& Morris, 2006). Whether functional or dysfunctional, repeated encounters with different experiences continue to challenge learning, understanding, and ability, thereby resulting in developmental changes (Mahoney, Gucciardi, et al., 2014). Examples of proximal processes in the retained studies include "tough physical practice environments" (Weinberg et al., 
2011), a "motivational climate that is challenging" (Connaughton et al., 2008), and "a challenging but supportive learning environment" (Cook et al., 2014).

Bronfenbrenner and Morris (2006) contextualised person as relating to performers being the producers as well as the products of their own development. The three processrelevant characteristics that partially determine this component include: (i) forces, which refers to the temperaments and motivations of individuals that promote both the degree and endurance of emotional and behavioural control; (ii) resources, which refers to the past experiences, skills, and different types of intelligence of developing individuals; and (iii) demands, which refers to the social expectations caused by the stimuli and information immediately available to others (e.g., gender, age, physical strength) when encountering a developing individual. These three characteristics are regularly being developed, revised, and refined as performers interact with their environment, emphasising the importance of viewing the development of this component as an ongoing process. Sharing similarities with the personal characteristics category identified in the primary research findings, further consideration allows us to identify examples of the three process-relevant characteristics: forces includes attributes such as "tough character, tough attitudes, and tough thinking" (Bull et al., 2005); resources include factors such as "psychological skills training" (Thelwell et al., 2010) or "reflective practice" (Connaughton et al., 2010); and demands include features such as "skill mastery" and "competitiveness" (Connaughton et al., 2010).

The third component of the model, known as contexts, incorporates the different physical and social environments that can influence a performer's development (Bronfenbrenner \& Morris, 2006), and aligns with the interactions within environment category. Contexts are said to comprise four systems: (i) microsystem: how a significant other (e.g., wife, husband) interacts with the performer; (ii) mesosystem: the relations between the family/domestic environment and other environments, such as a sporting club or 
workplace; (iii) exosystem: how the home role of a coach, or work role of a significant other (e.g., wife, husband) may influence the amount of time spent with the performer; and (iv) macrosystem: the effects from unique features of the performer's society, culture or community. Examples of ecological contexts in this meta-study include "coach-athlete relationship" (Gucciardi, Gordon, Dimmock, et al., 2009), interactions between “coaches, then parents, and teammates respectively" (Butt et al., 2010), and "sporting personnel, nonsporting personnel, [and] environmental influences" (Thelwell et al., 2010). Looking specifically at the prevalence of each of the four systems across the retained studies, more overt microsystems, such as coach-performer or parent-performer relationships were evident, and less so macrosystems, such as cultural influences. There were no direct references made to the mesosystem and exosystem, which were considered by Bronfenbrenner and Morris as continuing to influence development over the lifespan. It is noted that the relation between the home and training environment was considered as influencing a performer's early MT development (e.g., Gucciardi, Gordon, Dimmock, et al., 2009), but such factors were not identified as an important consideration during the later developmental stages.

The fourth component is time, in that a performer's development is influenced not just by what happens, but when it occurred during the lifespan (Bronfenbrenner \& Morris, 2006). The dimensions of this component include: (i) microtime: what happens during a single day of related activity; (ii) mesotime: what happens during a sequence of days of related activities; and (iii) macrotime: what happens during the life-span (or career) of those related activities. Aligning with the category identified earlier as breadth of experience, examples from the retained research include "providing learning opportunities" (Weinberg et al., 2011), “the coach's approach to workout planning” (Driska et al., 2012), as well as "successes (training and competition)" and "international competitive experience" (Connaughton et al., 2010). Although it would be useful to discuss which of these dimensions of time were 
considered most important for MT development, this interpretation cannot be offered as the most commonly reported finding was that MT develops over an extended period. There was also regular reference to the importance of significant events (or critical incidents) and a level of structure in training to facilitate MT development. However, limited detail was provided as to when these events were believed to be more or less effective during the developmental process, or specifically what these structured training programs should consist of and whether there were more or less effective periods for development. In light of this limited specificity among the findings in previous research, there is alignment with the time component through the identification that critical incidents throughout a performer's career are necessary for MT development (Connaughton et al., 2010; Connaughton et al., 2008; Driska et al., 2012; Gucciardi, Gordon, Dimmock, et al., 2009; Mahoney, Gucciardi, et al., 2014).

The application of the Bioecological framework to an example such as a critical incident presents an opportunity to clarify our understanding of the complex nature of the MT development process. It appears insufficient to focus on one specific component, such as exposing a performer to a critical incident, with the expectation that it will develop MT without consideration of the three other components. Therefore, the interdependent association between each of the four components is fundamental: without the appropriate proximal processes (e.g., challenging but supportive learning environment; Cook et al., 2014), person [characteristics/attributes] (e.g., reflective practice; Connaughton et al., 2010), and context (e.g., effective coach-athlete relationship; Gucciardi, Gordon, Dimmock, et al., 2009) in place during a critical incident, performers' responses may have an adverse effect on their MT development. Drawing the synthesis of extant qualitative MT development research into the PPCT framework (Bronfenbrenner \& Morris, 2006), the Bioecological Model of Mental Toughness Development is proposed as illustrated in Figure 2 (adapted from Krebs, 2009 proposed Bioecological Model of Sports Talent Development). The model 
provides a synthesis of previous MT development research and a theoretical framework to guide future research and theory advancement in the area of MT development.

\section{Discussion}

The primary purpose of this study was to create an integrated theoretical framework that incorporated extant MT development research and can serve to guide future work in this area. Three specific aims were addressed in this regard. First, our systematic review and evaluation of extant qualitative research resulted in the identification of a collection of key developmental factors and processes associated with MT development. Second, our synthesis of the existing knowledge resulted in its reinterpretation into four key categories that encompassed those factors highlighted as necessary for MT development: personal characteristics, interactions within environment, progressive development, and breadth of experience. Third, we generated an integrated framework (Figure 2) that explained the complexity of MT development, as well as offering an opportunity to inform and advance MT development research into the future.

Four main conclusions about the state of knowledge regarding MT development can be gleaned from our systematic evaluation and synthesis of qualitative research on this topic. First, the importance of understanding how individuals interact with their environment is key. It is difficult to understand one component (e.g., time) without considering how the other components may affect or be affected by it (e.g., the context of a performer's social environment). Although an individual's constructs or descriptions are often unique, they include shared meanings according to one's environmental domain at any given time (Bronfenbrenner \& Morris, 2006; Kelly 1955/1991). Therefore, the findings underscore the importance of a multi-systems or environment-dependent approach to MT development, regardless of age or career phase. Developing MT is complex and ongoing, involving a dynamic and reciprocal interplay between the person, processes, context, and time. In this 
sense, interactionism can involve transactions between performers and their dynamic environmental context, whereby performers can be shaped by, as well as influence their contexts (i.e., mutual dependency).

Second, performers are the authors and therefore active agents in their MT development. Bandura (2001) described agentic action as the process of an individual creating the most appropriate behaviour that will best promote the likelihood of his/her desired outcome. Therefore, as an agent of change, performers must play an active role to progress development across different areas, and maintain awareness that these different areas will also affect their future development. Further work is required to clarify our understanding of the strategies that might enable performers to play an agentic role in MT development over time (e.g., see Mahoney, Ntoumanis, Mallett, \& Gucciardi, 2014). Previous research has provided mostly a unidimensional approach to MT development (e.g., a coach providing MT learning opportunities, or training planning that developed MT, see Driska et al., 2012; Weinberg et al., 2011), with limited insight into the performer's necessary role in this process. It may be assumed that performers have to be willing to learn, but it is necessary to consider how a proactive approach might allow individuals to better facilitate their development as the primary agent of change (see Bindl, Parker, Totterdell, \& HaggerJohnson, 2012).

Third, minimal attention has been paid to differences in the developmental processes that may foster or hinder MT development. The interdependent relations between the four components of the model highlight the effects that aspects of the context, time, and/or performers' skills (characteristics/attributes) will likely have on their ability to develop. However, there has been limited investigation into how social contexts (e.g., coaching, practice, or team environments) at different developmental stages can either foster or hinder MT development, with a tendency to target more static contexts for investigation (e.g., once a 
performer has achieved full international honours, or once a coach has successfully trained elite performers). These methods do not allow for sufficient insight into how development is maintained long-term, whether it be prior to achieving success, following setbacks, or after success has been achieved. There remains limited understanding regarding the most conducive contexts that can maintain performers' motivation for continued development as a precursor to success, following setbacks, and once they have been successful.

The fourth key conclusion pertains to the traitness of MT. Although some scholars have suggested the concept is trait-like (e.g., Crust, 2007), recent evidence indicated that there is considerable intra-individual variability in MT (56\%), that is, one's MT levels fluctuate over time as a result of internal or external demands (Gucciardi, Hanton, et al., 2015). As Kenny and Zautra (2001) asserted, most psychological constructs exist on a continuum of stability, but vary over time and place. The findings of this meta-study support this assertion, and suggest that the degree of stability in one's MT levels may offer a unique approach to clarifying the importance of developmental processes. For example, athletes whose MT is unstable and fragile may be more vulnerable to the adverse effects of a critical incident, being less likely to identify potentialities and thus experience opportunities for growth and development. Indeed, subscribing to the view that MT is state-like and malleable appears to have important implications for cognitive, motivational and behavioural factors that could contribute to its development (Gucciardi, Jackson, Hodge, Anthony, \& Brooke, 2015).

\section{Methods, Methodologies and Theoretical Underpinnings}

This meta-study identified several important methodological and theoretical considerations for the study of MT development. First, when considering the applicability of the results to various performance domains, conjecture exists in the literature as to whether MT is a general or domain specific construct (Connaughton et al., 2011). In their research 
into MT development across the performance contexts of sport, academia, and music, Mahoney, Gucciardi, et al. (2014) identified consistencies across different performance contexts (cf. Butt et al., 2010). Another comparison between research conducted in individual performance domains, such as swimming (Driska et al., 2012), and multiple performance domains, such as Division 1 collegiate sports in the United States (Weinberg et al., 2011) did not highlight any major differences between the requirements for developing MT. However, Thelwell et al. (2010) reported some differences in perceptions of MT development between United States and United Kingdom gymnasts in their sample, attributing it to cultural factors such as the perceptions of increased national belief and support in the United States due to a greater interest in the sport.

To summarise, although there was consistency in the perceptions of MT development across the retained studies regardless of the performance domain (e.g., cricket vs swimming, single sport vs multiple sports), a minor point of difference was the cultural influences as a result of different nationalities. The influences of culture on sport are well-documented (see Jarvie, 2012 for a review), and there has been recent research that has started to consider the interplay between culture and MT in sport (e.g., Andersen, 2011; Caddick \& Ryall, 2012). What is unclear is whether or not MT development processes differ between a swimmer in the USA compared to a swimmer in China, with more detailed research necessary into how broader cultural differences might influence the MT development process. Such a consideration highlights the value of using the Bioecological model as a framework for future research design to ensure the broader macrosystems are addressed alongside consideration of other systems operating within contexts. Given the complex hierarchy of ecological contexts, and the interactions that go along with these settings, there is a need for methodological diversity. An example might be to employ an ethnographic design (Krane \& Baird, 2005) in an attempt to provide clarity with regard to the lived experience of MT development, as well 
as case studies (Mahoney, Anderson, Miles, \& Robinson, 2002) to capture in-depth perspectives of the multiple aspects of MT development.

Second, there remains a reliance on the retrospective accounts of performers and coaches, which has also been a criticism of previous MT research (Connaughton et al., 2011). Given that MT development appears to involve a complex interaction between the person, processes, contexts, and time, it is necessary to consider diverse data collection methods in future research (e.g., observation, dialogic or confrontational interviews, daily diaries for enhanced momentary recall). Such methodological diversity will also provide an opportunity for comprehensive data to be collected by capturing MT development as it progressively occurs, minimising the limitations associated with retrospective reporting, such as recall bias (Ross, 1989). With the notion of time central to the core findings of this meta-study, MT development research requires longitudinal studies to gather detailed information on the changes in processes over time (e.g., interviewing people multiple times over the course of a competitive season).

Third, the sample sizes ranged between seven and 18 participants across the MT development research. Although sample size in qualitative research is not as important if other conditions are met (e.g., saturation), there were some concerns identified as a result of the type of sampling methods. The prevailing approach in the retained studies was to draw on a purposive sample, yet there was often limited information regarding the determination of sizes (e.g., Connaughton et al., 2010; Cook et al., 2014; Weinberg et al., 2011), with sample size seemingly most related to whomever consented to being involved in the research. As Guetterman (2015) highlighted, the procedural details of sampling practices are necessary to allow for the progression of qualitative research. Furthermore, O'Reilly and Parker (2013) identified that continuing qualitative research until saturation is reached allows for a comprehensive reflection of the depth and breadth of the topic of interest. It is noted that 
these concerns are regularly cited as being difficult to avoid in qualitative research (Braun \& Clarke, 2006), but it should remain a consideration when designing qualitative research and interpreting such data.

There were also inconsistencies across the research regarding the identification of who is considered mentally tough, what level of performance must be reached, and how many years' experience is required for a participant to be a valid source of information on MT development. Connaughton et al. (2010) identified 'international competitive experience' as one factor necessary to develop MT, yet there are performance environments (i.e., academia, indigenous sports such as Australian football or American football/Gridiron) that may not have legitimate variations of the Olympics or world championships. If such a prerequisite was applied to the retained research, at least five of the samples fall short of this standard. Furthermore, in their research into what constitutes high performance across most domains, Ericsson, Krampe, and Tesch-Römer (1993) identified that the best performers of their expert sample had accumulated an average of 10,000 hours of deliberate practice at age 20. More recently, Ericsson (2013) clarified that for an individual to achieve elite adult performance in an area, there is a requirement to engage in regular deliberate practice from a young age. Applying this theory to the studies involving coaches or support staff, it is unclear whether any of the five samples have engaged in sufficient professional development, or deliberate practice, in the area of developing MT to provide valid insight into what is required to coach or develop MT. Additionally, if the recently proposed taxonomy of what constitutes sport expertise by Swann, Moran, and Piggott (2015) was applied, additional concerns regarding some of the samples not having sufficient expertise to provide insight into developing MT are highlighted. Key here is that scholars clearly justify the inclusion of their sample based on the philosophical underpinnings of the theoretical or methodological approach, and the specific objectives of their study. 
Fourth, a range of approaches were identified in terms of preparing participants for the interview. For example, in their research with gymnasts, Thelwell et al. (2010) reported that they provided Jones and colleagues' (2002) definition of MT and the key attributes to each participant prior to the interview. These approaches may increase the likelihood of priming participants to answer in ways that suit the authors' prescribed theory (Moss \& Lawrence, 1997), and thereby influence the participants' unique perspectives of what they view as important for MT development from their own experiences. Three other studies drew their sample from previous MT research participants (e.g., Connaughton et al., 2010; Connaughton et al., 2008; Gucciardi, Gordon, Dimmock, et al., 2009), which may have allowed for increased quality of the data; that is, the participants had previous opportunity to explore in-depth their own perspectives of the concept of MT, which would likely result in an enhanced familiarity with the researchers and the topic under investigation. Alternatively, some studies contained limited details regarding their specific interview procedures (e.g., Weinberg et al., 2011). As a result, questions can be raised about both the trustworthiness and credibility of research findings (Paterson et al., 2001), due to the difficulties making comparisons with other similar studies, or replicating the research. Concerns regarding replication are a contemporaneous issue for psychological research (Pashler \& Wagenmakers, 2012), so the provision of sufficient information for replication and expansion of research would seem to be crucially important.

\section{Future Directions}

The results of this meta-study can serve as a foundation for future research on MT development. We acknowledge that there are other models, such as Mahoney, Ntoumanis, et al.'s (2014) suggestion for Self-Determination Theory (SDT; Deci \& Ryan, 2000), that may have some utility for this purpose, yet offer Bronfenbrenner and Morris's (2006) Bioecological Model of Human Development as a viable option. Regardless of the 
theoretical model, attempts to improve the methods and methodologies using the suggestions herein will allow valuable progression in our understanding of MT development. The interdependent relationships between the person and context(s) appear central to an enhanced understanding of MT development. If the definition of MT used in this article is revisited, "a personal capacity to deliver high performance on a regular basis despite varying degrees of situational demands" (Gucciardi \& Hanton, in press, p. x), then the development of MT requires an approach that addresses the interactions between one's personal capacity (i.e., person), and accounts for those varying degrees of situational demands (i.e., contexts). Even in Jones et al.'s (2002) seminal MT definition, phrases such as "coping better" or "being more consistent" seem to highlight the importance of this person-context approach. If performers are to develop their MT, they must develop the ability to first interpret and then respond appropriately (e.g., cope better, or be more consistent) across a range of situations, which emphasises the importance of considering this interdependent association.

Previous research on MT development has focused on identifying key cognitions (e.g., optimistic thinking) and attributes (e.g., self-belief), with limited exploration of the necessary behaviours or, more specifically, what a performer is required to do to facilitate MT development. Hardy et al. (2014) recently proposed that MT can be defined as "The ability to achieve personal goals in the face of pressure from a wide range of different stressors" (p.70). Their definition also provided an overt connection to behaviourism, in that mentally tough behaviour is required to achieve personal goals in any given situation, regardless of the cognitions, attitudes, and emotions at play (see also Bell et al., 2013; Gucciardi, Peeling, Ducker, \& Dawson, in press). As a formative field in psychology, behaviourism focuses on how someone behaves and what can be observed, as opposed to the internal influences that cannot be seen (Bargh \& Ferguson, 2000). Research in this field has provided a foundation for the scientific development of psychological models that have been 
applied across many situations and environments (Eldridge \& Dembkowski, 2012).

Behavioural information remains an under-studied aspect of MT development, yet offers an opportunity to explore more concrete factors that may assist in furthering our understanding. Behavioural data also offers an opportunity to draw on the behaviourism literature that may allow enhanced conceptual understanding.

\section{Conclusion}

To our knowledge, the application of the meta-study approach in the current paper is the first systematic review to synthesise the qualitative MT development literature. It has resulted in what we believe is an enhanced understanding of the MT development literature, and subsequently provided qualification of extant research for future concept development. The Bioecological Model of Mental Toughness Development, which integrates past work on MT development with established theory of human development, offers a summary of the current state of affairs as well as a heuristic for future work in this area. The model can be used to guide research into MT program development, highlighting the various competing demands faced by an elite performer at any given stage during their career. Although a comprehensive intervention that adequately addresses each of the four factors may be unachievable, this model identifies those inter-related areas that can be targeted to develop MT (e.g., evolving proximal processes to foster the development of a performer's characteristics/attributes over time). Subsequently, the model offers enhanced clarity regarding both the developmental factors (e.g., who, when, and where) and processes (e.g., what and how) of MT via the inter-related components of PPCT (e.g., proximal processes, performer characteristics/attributes, contexts, and time). The model also emphasises the importance of the ongoing multi-layered interactions that occur between the performer, coach, and organisation, as well as external forces such as family, social, and cultural environments. Overall, the model allows an opportunity to shift the focus for the next 
iteration of MT development research using a well-supported developmental model, providing an emphasis on the interdependent process-person-context-time components, herein identified as important aspects of MT development. 


\section{References}

NOTE: $(*)$ indicates references that were retained for analysis as a part of this meta-study.

Andersen, M. B. (2011). Who's mental, who's tough and who's both? Mutton constructs dressed up as lamb. In D. F. Gucciardi \& S. Gordon (Eds.), Mental Toughness in Sport: Developments in Theory and Research (pp. 69-88). Abingdon, Oxon: Routledge.

Bandura, A. (2001). Social cognitive theory: An agentic perspective. Annual Review of Psychology, 52, 1-26. doi: 10.1146/annurev.psych.52.1.1

Bargh, J. A., \& Ferguson, M. J. (2000). Beyond behaviorism: On the automaticity of higher mental processes. Psychological Bulletin, 126, 925-945. doi: 10.1037/00332909.126.6.925

Bell, J. J., Hardy, L., \& Beattie, S. (2013). Enhancing mental toughness and performance under pressure in elite young cricketers: A 2-year longitudinal intervention. Sport, Exercise, and Performance Psychology, 2, 281-297. doi: 10.1037/a0033129

Bindl, U. K., Parker, S. K., Totterdell, P., \& Hagger-Johnson, G. (2012). Fuel of the selfstarter: How mood relates to proactive goal regulation. Journal of Applied Psychology, 97, 134-150. doi: 10.1037/a0024368

Braun, V., \& Clarke, V. (2006). Using thematic analysis in psychology. Qualitative Research in Psychology, 3, 77-101. doi: 10.1191/1478088706qp063oa

Britten, N., Campbell, R., Pope, C., Donovan, J., Morgan, M., \& Pill, R. (2002). Using meta ethnography to synthesise qualitative research: a worked example. Journal of Health Services Research \& Policy, 7, 209-215. doi: 10.1258/135581902320432732

Bronfenbrenner, U., \& Morris, P. A. (2006). The bioecological model of human development. In R. M. Lerner (Ed.), Handbook of child development: Theoretical models of human development (6th ed., Vol. 1, pp. 793-828). Hoboken, NJ: Wiley.

*Bull, S. J., Shambrook, C. J., James, W., \& Brooks, J. E. (2005). Towards an understanding of mental toughness in elite English cricketers. Journal of Applied Sport Psychology, 17, 209-227. doi: 10.1080/10413200591010085

*Butt, J., Weinberg, R., \& Culp, B. (2010). Exploring mental toughness in NCAA athletes. Journal of Intercollegiate Sport, 3, 316-332.

Caddick, N., \& Ryall, E. (2012). The social construction of mental toughness - A fascistoid ideology? Journal of the Philosophy of Sport, 39, 137-154. doi: 
Campbell, M., Fitzpatrick, R., Haines, A., Kinmonth, A. L., Sandercock, P., Spiegelhalter, D., \& Tyrer, P. (2000). Framework for design and evaluation of complex interventions to improve health. British Medical Journal, 321, 694-696.

CASP. (2014). Critical Appraisal Skills Programme Checklists. Retrieved 29th October, 2014, from http://www.casp-uk.net/\#!casp-tools-checklists/c18f8

Collins, J. A., \& Fauser, B. C. J. M. (2005). Balancing the strengths of systematic and narrative reviews. Human Reproduction Update, 11, 103-104. doi:

10.1093/humupd/dmh058

*Connaughton, D., Hanton, S., \& Jones, G. (2010). The development and maintenance of mental toughness in the world's best performers. Sport Psychologist, 24, 168-193.

Connaughton, D., Thelwell, R., \& Hanton, S. (2011). Mental toughness development: Issues, practical implications and future directions. In D. F. Gucciardi \& S. Gordon (Eds.), Mental toughness in sport: Developments in research and theory (pp. 136-162). Abingdon, Oxon: Routledge.

*Connaughton, D., Wadey, R., Hanton, S., \& Jones, G. (2008). The development and maintenance of mental toughness: Perceptions of elite performers. Journal of Sports Sciences, 26, 83-95. doi: 10.1080/02640410701310958

*Cook, C., Crust, L., Littlewood, M., Nesti, M., \& Allen-Collinson, J. (2014). 'What it takes': Perceptions of mental toughness and its development in an English Premier League soccer academy. Qualitiative Research in Sport, Exercise and Health, 6, 329-347. doi: 10.1080/2159676X.2013.857708

Crust, L. (2007). Mental toughness in sport: A review. International Journal of Sport \& Exercise Psychology, 5, 270-290.

Deci, E. L., \& Ryan, R. M. (2000). The" what" and" why" of goal pursuits: Human needs and the self-determination of behavior. Psychological inquiry, 11, 227-268.

*Driska, A. P., Kamphoff, C., \& Armentrout, S. M. (2012). Elite swimming coaches' perceptions of mental toughness. Sport Psychologist, 26, 189-206.

Eldridge, F., \& Dembkowski, S. (2012). Behavioral Coaching. In J. Passmore, D. B. Peterson, \& T. Freire (Eds.), The Wiley-Blackwell handbook of the psychology of coaching and mentoring (pp. 298-318). Oxford, UK: John Wiley \& Sons.

Ericsson, K. A. (2013). Training history, deliberate practice and elite sports performance: an analysis in response to Tucker and Collins review_what makes champions? British Journal of Sports Medicine, 47, 533-535. doi: 10.1136/bjsports-2012-091767 
Ericsson, K. A., Krampe, R. T., \& Tesch-Römer, C. (1993). The role of deliberate practice in the acquisition of expert performance. Psychological review, 100, 363-406. doi: 10.1037/0033-295X.100.3.363

Gergen, K. J. (2009). Relational being: Beyond self and community. Oxford: Oxford University Press.

Gray, J. A., \& McNaughton, N. (2000). The neuropsychology of anxiety: An enquiry into the functions of the septo-hippocampal system. Oxford: Oxford University Press.

Gucciardi, D. F., Gordon, S., \& Dimmock, J. A. (2009). Evaluation of a mental toughness training program for youth-aged Australian footballers I: A quantitative analysis. Journal of Applied Sport Psychology, 21, 307-323. doi: 10.1080/10413200903026066

*Gucciardi, D. F., Gordon, S., Dimmock, J. A., \& Mallett, C. J. (2009). Understanding the coach's role in the development of mental toughness: Perspectives of elite Australian football coaches. Journal of Sports Sciences, 27, 1483-1496. doi:

10.1080/02640410903150475

Gucciardi, D. F., \& Hanton, S. (in press). Mental Toughness: Critical reflections and future considerations. In R. Schinke, K. McGannon, \& B. Smith (Eds.), The Routledge international handbook of sport psychology: Routledge.

Gucciardi, D. F., Hanton, S., Gordon, S., Mallett, C. J., \& Temby, P. (2015). The concept of mental toughness: Tests of dimensionality, nomological network, and traitness. Journal of Personality, 83, 26-44. doi: 10.1111/jopy.12079

Gucciardi, D. F., Jackson, B., Hodge, K., Anthony, D. R., \& Brooke, L. (2015). Implicit theories of mental toughness: Relations with cognitive, motivational, and behavioral correlates. Sport, Exercise, and Performance Psychology, 4, 100-112. doi: $10.1037 /$ spy0000024

Gucciardi, D. F., Peeling, P., Ducker, K. J., \& Dawson, B. (in press). When the going gets tough: Mental toughness and its relationship with behavioural perseverance. Journal of Science and Medicine in Sport. doi: http://dx.doi.org/10.1016/j.jsams.2014.12.005

Guetterman, T. C. (2015). Descriptions of sampling practices within five approaches to qualitative research in education and the health sciences. Forum Qualitative Sozial Forschung, 16, 1-23.

Gulbin, J. P., Croser, M. J., Morley, E. J., \& Weissensteiner, J. R. (2013). An integrated framework for the optimisation of sport and athlete development: A practitioner approach. Journal of Sports Sciences, 31, 1319-1331. doi:

$10.1080 / 02640414.2013 .781661$ 
Hardy, L., Bell, J., \& Beattie, S. (2014). A neuropsychological model of mentally tough behavior. Journal of Personality, 82, 69-81. doi: 10.1111/jopy.12034

Jarvie, G. (2012). Sport, culture and society: An introduction (2nd ed.). New York: Routledge.

Jones, G., Hanton, S., \& Connaughton, D. (2002). What is this thing called mental toughness? An investigation of elite sport performers. Journal of Applied Sport Psychology, 14, 205-218. doi: 10.1080/10413200290103509

Jones, G., Hanton, S., \& Connaughton, D. (2007). A framework of mental toughness in the world's best performers. Sport Psychologist, 21, 243-264.

Kelly, G. A. (1991). The psychology of personal constructs: A theory of personality (Vol. 1). London: Routledge (Original work published 1955).

Kenny, D. A., \& Zautra, A. (2001). The trait-state models for longitudinal data. In L. M. Collins \& A. G. Sayer (Eds.), New methods for the analysis of change (pp. 243-263). Washington, DC: American Psychological Association.

Krane, V., \& Baird, S. M. (2005). Using ethnography in applied sport psychology. Journal of Applied Sport Psychology, 17, 87-107.

Krebs, R. J. (2009). Bronfenbrenner's bioecological theory of human development and the process of development of sports talent. International Journal of Sport Psychology, 40, 108-135.

Mahoney, C., Anderson, A. G., Miles, A., \& Robinson, P. (2002). Evaluating the effectiveness of applied sport psychology practice: Making the case for a case study approach. Sport Psychologist, 16, 433-454.

*Mahoney, J. W., Gucciardi, D. F., Mallett, C. J., \& Ntoumanis, N. (2014). Adolescent performers' perspectives on mental toughness and its development: The utility of the bioecological model. The Sport Psychologist, 28, 233-244. doi: 10.1123/tsp.20130050

Mahoney, J. W., Ntoumanis, N., Mallett, C. J., \& Gucciardi, D. F. (2014). The motivational antecedents of the development of mental toughness: A self-determination theory perspective. International Review of Sport and Exercise Psychology, 7, 184-197. doi: 10.1080/1750984X.2014.925951

Miles, M. B., \& Huberman, A. M. (1994). Qualitative data analysis: An expanded sourcebook (2nd ed.). Thousand Oaks, CA: Sage. 
Moher, D., Liberati, A., Tetzlaff, J., Altman, D. G., \& The PRISMA Group (2009). Preferred reporting items for systematic reviews and meta-analyses: The PRISMA statement. PLoS Med, 6. doi:10.1371/journal.pmed1000097

Moss, S. E., \& Lawrence, K. G. (1997). The effects of priming on the self-reporting of perceived stressors and strains. Journal of Organizational Behavior, 18, 393-403. doi: 10.1002/(SICI)1099-1379(199707)18:4\%3C393::AID-JOB809\%3E3.0.CO;2-5

Noblit, G. W., \& Hare, R. D. (1988). Meta-ethnography: Synthesizing qualitative studies. Newbury Park, CA: Sage.

O'Reilly, M., \& Parker, N. (2013). 'Unsatisfactory Saturation': A critical exploration of the notion of saturated sample sizes in qualitative research. Qualitative Research, 13, 190-197. doi: $10.1177 / 1468794112446106$

Pashler, H., \& Wagenmakers, E. (2012). Editors' introduction to the special section on replicability in psychological science: A crisis in confidence? Perspectives in Psychological Science, 7, 528-530. doi: 10.1177/1745691612465253

Paterson, B. L., Thorne, S. E., Canam, C., \& Jillings, C. (2001). Meta-study of qualitative health research: A practical guide to meta-analysis and meta-synthesis. Thousand Oaks, CA: Sage.

Patton, M. Q. (2002). Qualitative evaluation and research methods (3rd ed.). Newbury Park, CA: Sage.

Ritzer, G. (1992). Sociological theory (3rd ed.). New York: McGraw-Hill.

Ross, M. (1989). Relation of implicit theories to the construction of personal histories. Psychological review, 96, 341-357. doi: 10.1037/0033-295X.96.2.341

Sandelowski, M., \& Barroso, J. (2003). Toward a metasynthesis of qualitative findings on motherhood in HIV-positive women. Research in Nursing \& Health, 26, 153-170. doi: 10.1002/nur.10072

Sandelowski, M., Docherty, S., \& Emden, C. (1997). Qualitative metasynthesis: Issues and techniques. Research in Nursing and Health, 20, 365-371. doi: 10.1002/(SICI)1098240X(199708)20:4<365::AID-NUR9>3.0.CO;2-E

Sheard, M., \& Golby, J. (2006). Effect of a psychological skills training program on swimming performance and positive psychological development. International Journal of Sport and Exercise Psychology, 4, 149-169. doi:

10.1080/1612197X.2006.9671790 
Swann, C., Moran, A., \& Piggott, D. (2015). Defining elite athletes: Issues in the study of expert performance in sport psychology. Psychology of Sport and Exercise, 16, Part 1, 3-14. doi: http://dx.doi.org/10.1016/j.psychsport.2014.07.004

Tamminen, K. A., \& Holt, N. L. (2010). A meta-study of qualitative research examining stressor appraisals and coping among adolescents in sport. Journal of Sports Sciences, 28, 1563-1580. doi: 10.1080/02640414.2010.512642

*Thelwell, R. C., Such, B. A., Weston, N. J. V., Such, J. D., \& Greenlees, I. A. (2010). Developing mental toughness: Perceptions of elite female gymnasts. International Journal of Sport and Exercise Psychology, 8, 170-188. doi: 10.1080/1612197X.2010.9671941

Vaeyens, R., Lenoir, M., Williams, A. M., \& Philippaerts, R. M. (2008). Talent identification and development programmes in sport. Sports Medicine, 38, 703-714. doi: $10.2165 / 00007256-200838090-00001$

Walsh, D., \& Downe, S. (2005). Meta-synthesis method for qualitative research: A literature review. Journal of Advanced Nursing, 50, 204-211. doi: 10.1111/j.13652648.2005.03380.x

*Weinberg, R., Butt, J., \& Culp, B. (2011). Coaches' views of mental toughness and how it is built. International Journal of Sport and Exercise Psychology, 9, 156-172. doi: 10.1080/1612197X.2011.567106 
8300 records identified from computer database search (using the search platforms of Web of Science, Scopus, Sport Discus, OvidSP, and Google Scholar).

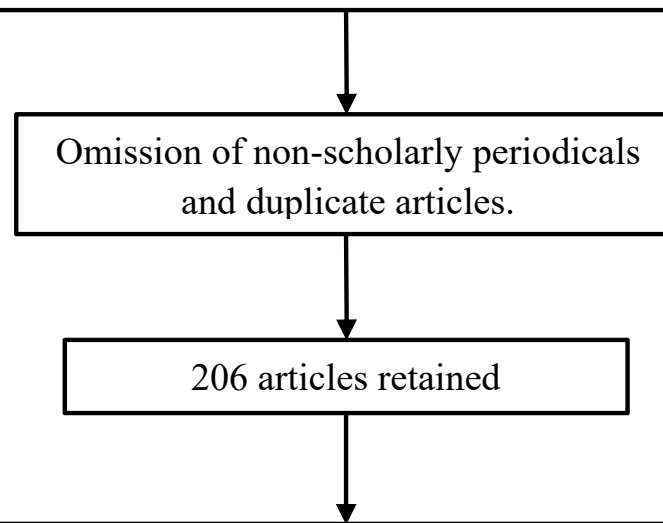

Visual scan of abstracts for the phrase "mental toughness" or "mentally tough", rejection of articles against the exclusion criteria (e.g., quantitative studies only, non-sport/performance settings, review articles)

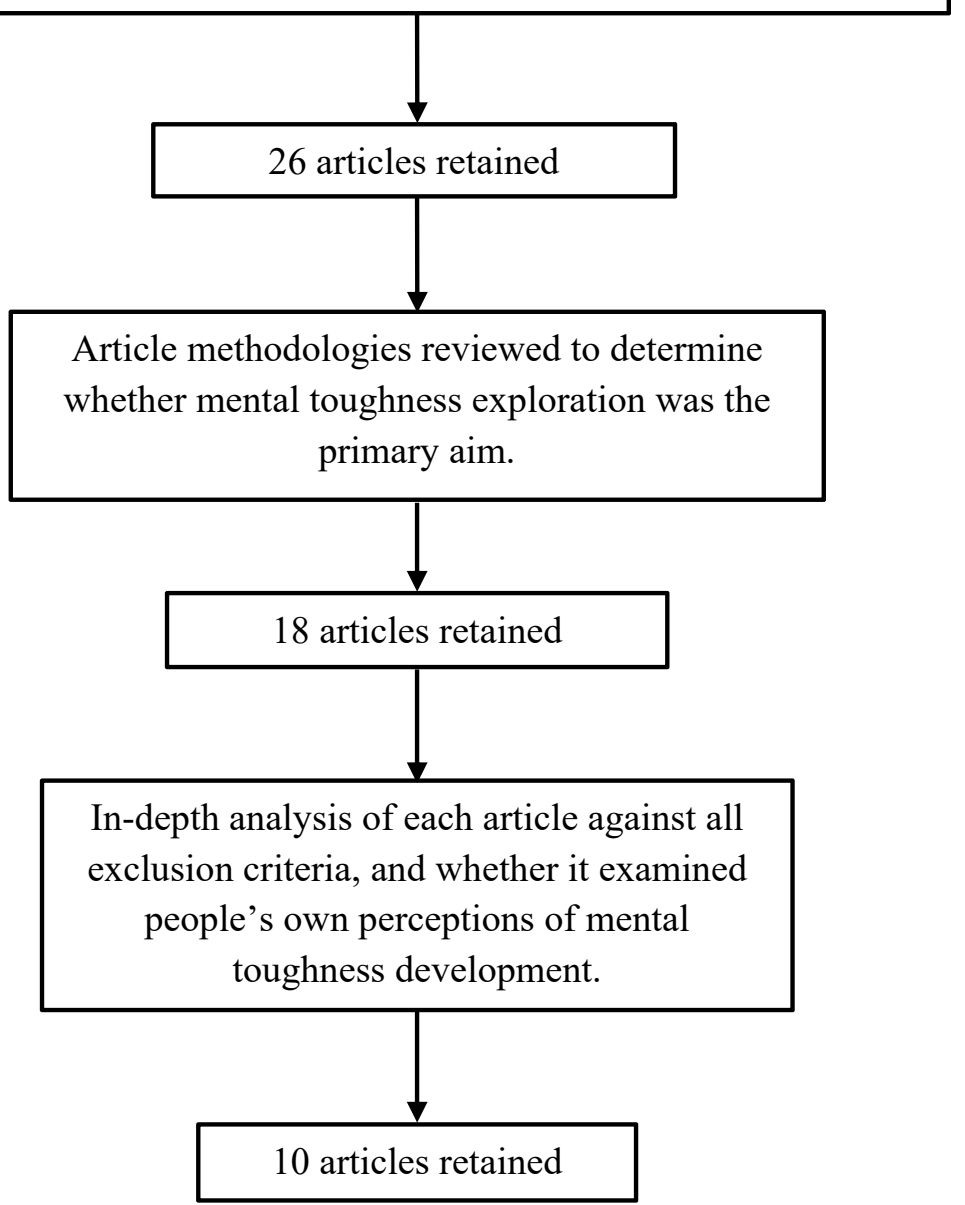

Figure 1. Flow diagram of search and retrieval strategies 


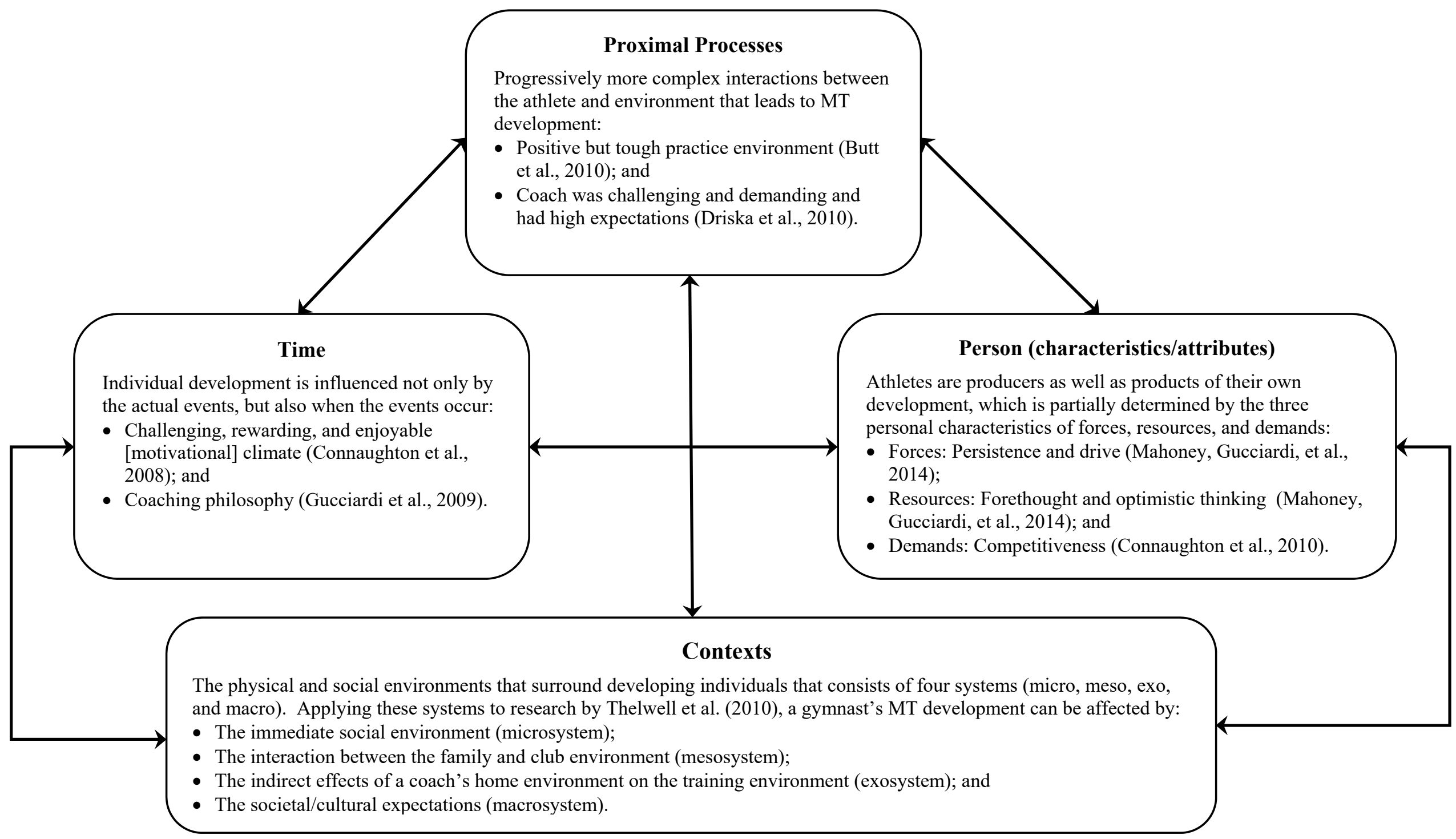

Figure 2. The Bioecological model of Mental Toughness Development (adapted from Krebs, 2009, p. 132). 
Table 1. Key features of primary research reports.

\begin{tabular}{|c|c|c|c|c|c|}
\hline Study & Theoretical basis & Sampling method & Sample characteristics & Data collection & Data analysis \\
\hline Bull et al. (2005). & $\begin{array}{l}\text { - Existing background MT } \\
\text { research by research } \\
\text { team. } \\
\text { - Jones et al. (2002) } \\
\text { definition of MT. } \\
\text { - Gould, Dieffenbach, and } \\
\text { Moffett's (2002) } \\
\text { research. }\end{array}$ & $\begin{array}{l}\text { Participants identified by } 101 \\
\text { cricket coaches when asked to } \\
\text { identify the "mentally toughest" } \\
\text { performers from } 1980 \text { 's and } \\
1990 \text { 's; Cultural consensus } \\
\text { sample. }\end{array}$ & $\begin{array}{l}12 \text { male cricket players; Age } \\
\text { range not specified; All played at } \\
\text { international level for England; } \\
\text { Ethnicity not stated. }\end{array}$ & $\begin{array}{l}\text { - 1-1 qualitative semi-structured interviews. } \\
\text { - Interview setting not specified apart from "... } \\
\text { interviewed at a time and location convenient to } \\
\text { them [participant]". } \\
\text { - Interview preceded by a general information } \\
\text { package on reasons for interview, but no } \\
\text { specific information relating to } \\
\text { conceptualisation of MT. }\end{array}$ & $\begin{array}{l}\text { - Analysis guided primarily through the } \\
\text { presentation and discussion of direct } \\
\text { quotations from transcripts by two } \\
\text { members of the research team. } \\
\text { - Focus group to "interrogate" } 10 \\
\text { categories and emerging themes. }\end{array}$ \\
\hline Butt et al. (2010). & $\begin{array}{l}\text { - Jones et al. (2002) MT } \\
\text { definition. } \\
\text { - Psychological } \\
\text { characteristics of } \\
\text { successful athletes, and } \\
\text { psychology of excellence } \\
\text { (e.g., Gilbert \& Trudel, } \\
\text { 2004; Gould et al., 2002). }\end{array}$ & $\begin{array}{l}\text { Participants identified by their } \\
\text { coaches as having "mental } \\
\text { toughness qualities" with } \\
\text { minimum of one year } \\
\text { experience at NCAA Division } \\
1 \text { competition; Purposive } \\
\text { sample. }\end{array}$ & $\begin{array}{l}15 \text { collegiate NCAA Division } 1 \\
\text { athletes ( } 9 \text { males, } 6 \text { females); Age } \\
\mathrm{M}=20.0 \text { ( } \mathrm{SD}=0.91) \text {; Sample } \\
\text { drawn from a range of sports in } \\
\text { USA; Ethnicity not stated. }\end{array}$ & $\begin{array}{l}\text { - } 1-1 \text { qualitative semi-structured } \\
\text { interviews. } \\
\text { - All interviews conducted face-to-face by the } \\
\text { same individual. } \\
\text { - Preceded by a brief discussion via phone about } \\
\text { MT: Athletes asked if they considered } \\
\text { themselves MT, and in what situations they } \\
\text { demonstrated it. }\end{array}$ & $\begin{array}{l}\text { - Content analysis by three investigators, } \\
\text { with analyst triangulation. }\end{array}$ \\
\hline $\begin{array}{l}\text { Connaughton et } \\
\text { al. (2010). }\end{array}$ & $\begin{array}{l}\text { - Jones et al. (2007) MT } \\
\text { framework (4 dimensions } \\
\text { and } 12 \text { subcomponents). } \\
\text { - Bloom's (1985) and } \\
\text { Cote, Baker, and } \\
\text { Abernethy's (2003) three } \\
\text { career phases of talent } \\
\text { and expertise } \\
\text { development. }\end{array}$ & $\begin{array}{l}\text { Participants classified as "Super } \\
\text { elite"; Performers averaged } 7 \\
\text { years' experience at } \\
\text { international level; } \\
\text { Coaches/sport psychologists } \\
\text { involved at the same level } \\
\text { between 7-20 years; Purposive } \\
\text { sample (from previous study). }\end{array}$ & $\begin{array}{l}11 \text { respondents ( } 4 \text { male and } 3 \\
\text { female performers, } 2 \text { male } \\
\text { coaches, } 2 \text { male sport } \\
\text { psychologists) from a range of } \\
\text { sports; Aged } 25-62 \text { years; } \\
\text { International experience at } \\
\text { Olympics or commonwealth } \\
\text { games for either Australia, } \\
\text { England, Canada, or Wales; } \\
\text { Ethnicity not stated. }\end{array}$ & $\begin{array}{l}\text { - 1-1 qualitative semi-structured interviews. } \\
\text { - Interviews conducted face-to-face. } \\
\text { - For performers only, a quantitative } \\
\text { "involvement progression questionnaire" } \\
\text { adapted from Bloom's (1985) and Cote et al.'s } \\
\text { (2003) three career phases of talent and } \\
\text { expertise development. } \\
\text { - Interview guides distributed to participants two } \\
\text { weeks prior to interview. }\end{array}$ & $\begin{array}{l}\text { - Coded into framework dimensions and } \\
\text { subcomponents using a seven step } \\
\text { process by the research team. } \\
\text { - Coding involved deductively analysing } \\
\text { the transcripts; peer debriefing, and } \\
\text { member-checking. }\end{array}$ \\
\hline
\end{tabular}


A Meta-study of MT Development 40

\begin{tabular}{|c|c|c|c|c|c|}
\hline Study & Theoretical basis & Sampling method & Sample characteristics & Data collection & Data analysis \\
\hline $\begin{array}{l}\text { Connaughton et } \\
\text { al. (2008). }\end{array}$ & $\begin{array}{l}\text { - Jones et al. (2002) MT } \\
\text { attributes. } \\
\text { - Bloom's (1985) career } \\
\text { phases of development. }\end{array}$ & $\begin{array}{l}\text { Participants classified as "Super } \\
\text { elite"; Average of } 7 \text { years' } \\
\text { experience at international } \\
\text { level; Purposive sample (from } \\
\text { previous study). }\end{array}$ & $\begin{array}{l}\text { Seven athletes ( } 5 \text { males, } 2 \\
\text { females) from a range of sports; } \\
\text { Age } \mathrm{M}=33(\mathrm{SD}=5.3) ; \\
\text { International experience at } \\
\text { Olympics or World } \\
\text { championships; Nationality and } \\
\text { Ethnicity not stated. }\end{array}$ & $\begin{array}{l}\text { - 1-1 qualitative semi-structured interviews. } \\
\text { - Interviewed either face to face or via phone. } \\
\text { - Participants provided with a preparation booklet } \\
\text { one week prior to interview. }\end{array}$ & $\begin{array}{l}\text { - Deductive analysis, including } \\
\text { triangulation, peer-debriefing, referential } \\
\text { adequacy, member checking, thick } \\
\text { description, and stepwise replication. }\end{array}$ \\
\hline Cook et al. (2014) & $\begin{array}{l}\text { Draws on MT research } \\
\text { findings and } \\
\text { recommendations from } \\
\text { previous studies (Bull et } \\
\text { al. 2005; Connaughton et } \\
\text { al. 2008; Thelwell, } \\
\text { Weston, \& Greenlees, } \\
\text { 2005) alongside authors' } \\
\text { own theoretical interests. }\end{array}$ & $\begin{array}{l}\text { Participants classified as } \\
\text { "highly experienced" with } 18 \\
\text { years (range 6-27) of } \\
\text { employment at the professional } \\
\text { level; Purposive sample. }\end{array}$ & $\begin{array}{l}\text { Eight coaching }(n=3) \text { and support } \\
\text { staff }(n=5) ; \text { Age and gender not } \\
\text { specified; Professional level } \\
\text { (English premier league soccer } \\
\text { academy); Nationality and } \\
\text { Ethnicity not stated. }\end{array}$ & $\begin{array}{l}\text { - 1-1 qualitative semi-structured interviews. } \\
\text { - Interviews face-to-face in participant's office. } \\
\text { - No record of whether pre-reading was provided } \\
\text { to participants. }\end{array}$ & $\begin{array}{l}\text { - Thematic content analysis } \\
\text { by members of the research team. } \\
\text { Subsequently, themes were considered } \\
\text { and reviewed by two other researchers } \\
\text { (members of the research team) } \\
\text { independently. }\end{array}$ \\
\hline $\begin{array}{l}\text { Driska et al. } \\
\text { (2012). }\end{array}$ & $\begin{array}{l}\text { - Jones et al.'s (2007) four } \\
\text { dimensional MT } \\
\text { framework. }\end{array}$ & $\begin{array}{l}\text { Participants must have trained } \\
\text { national level athletes as a } \\
\text { minimum; coaching experience } \\
(\mathrm{M}=31.7 \text { years, } \mathrm{SD}=8.9) ; \\
\text { Purposive sample into snowball } \\
\text { method (initial participants } \\
\text { recommended other "suitable" } \\
\text { participants). }\end{array}$ & $\begin{array}{l}13 \text { swimming coaches ( } 9 \text { males, } 4 \\
\text { females); age } \mathrm{M}=61.2(\mathrm{SD}=10.0) \text {; } \\
\text { Trained athletes that have } \\
\text { succeeded at national level in } \\
\text { USA; Ethnicity not stated. }\end{array}$ & $\begin{array}{l}\text { - 1-1 qualitative semi-structured interviews via } \\
\text { phone. } \\
\text { - Participant's instructed at least one day before } \\
\text { the interview to recall one or two mentally } \\
\text { tough athletes they had coached within the past } \\
\text { five years. }\end{array}$ & $\begin{array}{l}\text { - Deductive (MT attributes) then inductive } \\
\text { (MT development) analysis, with a } \\
\text { system of peer-debriefing and analyst } \\
\text { triangulation. }\end{array}$ \\
\hline $\begin{array}{l}\text { Gucciardi et al. } \\
\text { (2009). }\end{array}$ & $\begin{array}{l}\text { - Gucciardi, Gordon, and } \\
\text { Dimmock's (2008) } \\
\text { conceptualisation of MT } \\
\text { in Australian Football. } \\
\text { - Tranckle and Cushion's } \\
\text { (2006) research into } \\
\text { factors that facilitate and } \\
\text { impede development. }\end{array}$ & $\begin{array}{l}\text { Participants had previous } \\
\text { experience as either head coach } \\
\text { or assistant coach of elite } \\
\text { Australian football team, with } \\
\text { state level coaching experience } \\
(\mathrm{M}=105, \mathrm{SD}=19.5 \text { ) and national } \\
\text { level coaching experience } \\
\text { (M=107, } \mathrm{SD}=25.2) \text {; Purposive } \\
\text { sample (from previous study). }\end{array}$ & $\begin{array}{l}11 \text { male Australian football } \\
\text { coaches; age } \mathrm{M}=42(\mathrm{SD}=9.62) \\
\text { Currently coaching state level or } \\
\text { national level in Australia; } \\
\text { Ethnicity not stated. }\end{array}$ & $\begin{array}{l}\text { - 1-1 qualitative semi-structured interviews. } \\
\text { - Delivered face to face. } \\
\text { Both the interview schedule and Gucciardi et } \\
\text { al.'s (2008) conceptualisation of MT in } \\
\text { Australian Football provided a minimum of } \\
\text { three days prior to the interview. }\end{array}$ & $\begin{array}{l}\text { - Grounded theory methodology to move } \\
\text { from description, through } \\
\text { conceptual categorizing, to relationship } \\
\text { building and theorizing. } \\
\text { - "Constant Comparative Analysis". }\end{array}$ \\
\hline
\end{tabular}


A Meta-study of MT Development 41

\begin{tabular}{|c|c|c|c|c|c|}
\hline Study & Theoretical basis & Sampling method & Sample characteristics & Data collection & Data analysis \\
\hline $\begin{array}{l}\text { Mahoney, } \\
\text { Gucciardi, et al. } \\
\text { (2014). }\end{array}$ & $\begin{array}{l}\text { - MT framework adapted } \\
\text { from previous MT } \\
\text { definitions (Coulter, } \\
\text { Mallett, \& Gucciardi, } \\
\text { 2010; Gucciardi et al., } \\
\text { 2008; Jones et al., 2007). } \\
\text { - Bronfenbrenner's (2001) } \\
\text { Bioecological Model. }\end{array}$ & $\begin{array}{l}\text { Participants identified by } \\
\text { faculty deans at high } \\
\text { performing independent } \\
\text { schools; Purposive sample. }\end{array}$ & $\begin{array}{l}18 \text { adolescent performers }(9 \\
\text { males, } 9 \text { females); aged } 13-17 \\
\text { years }(\mathrm{M}=15.6) \text {; Have performed } \\
\text { either the highest or second } \\
\text { highest teams or ensembles for } \\
\text { sport and music respectively, or } \\
\text { within the top } 20 \% \text { of the state } \\
\text { cohort for academia in Australia; } \\
\text { Ethnicity not stated. }\end{array}$ & $\begin{array}{l}\text { Two focus groups; brief worksheet in line with } \\
\text { PCP used initially, followed by group } \\
\text { discussions using a semi-structured interview } \\
\text { guide. } \\
\text { - Followed up by 1-1 qualitative semi-structured } \\
\text { interviews, with questions devised from the } \\
\text { focus group responses. } \\
\text { - All interviews conducted face-to-face. } \\
\text { - No additional information provided to } \\
\text { participants prior to interviews. }\end{array}$ & $\begin{array}{l}\text { - Initial coding using four-stage } \\
\text { interpretative phenomenological } \\
\text { procedure by three analysts. } \\
\text { - Subsequently, factors thought to } \\
\text { contribute to MT development were } \\
\text { analysed alongside the four properties of } \\
\text { the Bioecological Model (PPCT; } \\
\text { Brofenbrenner, 2001). }\end{array}$ \\
\hline $\begin{array}{l}\text { Thelwell et al. } \\
\text { (2010). }\end{array}$ & $\begin{array}{l}\text { Definition and key } \\
\text { attributes of MT adopted } \\
\text { from Jones et al. (2002). }\end{array}$ & $\begin{array}{l}\text { Participants accessed through } \\
\text { coaches, with the athletes } \\
\text { required to have "achieved full } \\
\text { international honours"; } \\
\text { Convenience sample. }\end{array}$ & $\begin{array}{l}10 \text { female gymnasts; aged } 15-22 \\
\text { International level competitors } \\
\text { from United States and England } \\
(n \text { from each country not stated); } \\
\text { Ethnicity not stated. }\end{array}$ & $\begin{array}{l}\text { - 1-1 qualitative semi-structured interviews. } \\
\text { - Interviews conducted face to face. } \\
\text { - Participants provided with a definition of MT } \\
\text { and key attributes prior to interview. }\end{array}$ & $\begin{array}{l}\text { - Inductive analysis initially by two } \\
\text { researchers independently to allow } \\
\text { themes to emerge from interviews, then } \\
\text { deductive in later stages to ensure } \\
\text { appropriate placement into higher order } \\
\text { themes. } \\
\text { - Followed by seeking consensus between } \\
\text { the first two and a third researcher. }\end{array}$ \\
\hline $\begin{array}{l}\text { Weinberg et al. } \\
\text { (2011). }\end{array}$ & $\begin{array}{l}\text { - Existing MT literature } \\
\text { (no further detail). } \\
\text { - "...explore MT during a } \\
\text { time-frame that is } \\
\text { considered critical to an } \\
\text { athlete's career (i.e., } \\
\text { varsity sport at the } \\
\text { collegiate level) in the } \\
\text { US" (p.159). }\end{array}$ & $\begin{array}{l}\text { Participants required to have at } \\
\text { least } 10 \text { years coaching } \\
\text { experience at Division } 1 \text { level } \\
\text { (Range 10-22 years; } M=11.9 \\
\text { SD=3.66); Purposive sample. }\end{array}$ & $\begin{array}{l}10 \text { coaches ( } 5 \text { males, } 5 \text { females) } \\
\text { from a range of sports; Age not } \\
\text { specified; NCAA Division } 1 \\
\text { experience of } 10 \text { years minimum } \\
\text { in USA; White ethnicity. }\end{array}$ & $\begin{array}{l}\text { - 1-1 qualitative semi-structured interviews. } \\
\text { - Interviews conducted face to face. } \\
\text { - No record of whether pre-reading was provided } \\
\text { to participants. }\end{array}$ & $\begin{array}{l}\text { - Inductive content analysis performed by } \\
\text { each of the three investigators } \\
\text { independently identifying raw data } \\
\text { themes for each question. }\end{array}$ \\
\hline
\end{tabular}


Table 2. Main findings from primary research reports.

\begin{tabular}{|c|c|c|c|}
\hline $\begin{array}{l}\text { Participant } \\
\text { role }\end{array}$ & Study & Important findings. How to develop $M T$. & $\begin{array}{l}\text { Relationship with previous } \\
\text { research }\end{array}$ \\
\hline $\begin{array}{l}\text { Performers } \\
\text { (cricket) }\end{array}$ & $\begin{array}{l}\text { Bull et al. } \\
(2005) \text {. }\end{array}$ & $\begin{array}{l}\text { - MT is developed through environmental influence, Tough } \\
\text { character, tough attitudes, and tough thinking. } \\
\text { - These factors interact with the general MT dimensions of } \\
\text { 'Developmental factors', 'Personal responsibility', } \\
\text { 'Dedication and commitment', 'Belief', and 'Coping with } \\
\text { pressure'. }\end{array}$ & $\begin{array}{l}\text { The global themes can readily be compared } \\
\text { to Jones et al.'s MT attributes. }\end{array}$ \\
\hline $\begin{array}{l}\text { Performers } \\
\text { (gymnastics) }\end{array}$ & $\begin{array}{l}\text { Thelwell et al. } \\
(2010) \text {. }\end{array}$ & $\begin{array}{l}\text { - Four general dimensions that contributed to gymnast } \\
\text { development of MT: sport process, sporting personnel, } \\
\text { non-sporting personnel, and environmental influences. } \\
\text { - Athletes and practitioners must be aware that } \\
\text { psychological skills training is just one mechanism for } \\
\text { developing MT. } \\
\text { - MT development viewed as a unidimensional construct. }\end{array}$ & $\begin{array}{l}\text { Support provided for previous research } \\
\text { findings that MT development is a complex } \\
\text { phenomenon. }\end{array}$ \\
\hline $\begin{array}{l}\text { Performers } \\
\text { (multiple } \\
\text { sports) }\end{array}$ & $\begin{array}{l}\text { Butt et al. } \\
(2010)\end{array}$ & $\begin{array}{l}\text { - Three higher order themes in strategies to build MT: } \\
\text { Positive but tough practice environment, enhancing psych } \\
\text { skills, and teaching MT. } \\
\text { - Creating a positive but tough practice environment } \\
\text { emerged as a dominant theme to build MT. } \\
\text { - Coaches (i.e., coaches' support, coaches' attributes, } \\
\text { coaches' practices), then parents and teammates } \\
\text { respectively were identified as having a role in } \\
\text { developing MT. } \\
\text { - MT development viewed as a unidimensional construct. } \\
\text { - Highlighted the relationship between life skills and MT in } \\
\text { sport. }\end{array}$ & $\begin{array}{l}\text { Findings were fairly consistent with previous } \\
\text { investigations (e.g.. Bull et al., 2005; Jones } \\
\text { et al., 2002; Jones et al., 2007; Thelwell et } \\
\text { al., 2005). }\end{array}$ \\
\hline $\begin{array}{l}\text { Performers } \\
\text { (multiple } \\
\text { sports) }\end{array}$ & $\begin{array}{l}\text { Connaughton et } \\
\text { al. (2008). }\end{array}$ & $\begin{array}{l}\text { - MT development is a long-term process that encompasses } \\
\text { a multitude of underlying mechanisms, which operate } \\
\text { collectively, including: 1. A motivational climate that is } \\
\text { challenging, rewarding, and enjoyable; } \\
\text { 2. Encouragement from significant others who also act as } \\
\text { a resource of knowledge and inspiration; and 3. The } \\
\text { experience of critical incidents (e.g. setbacks, anxiety). } \\
\text { - MT development viewed as a multidimensional construct. }\end{array}$ & $\begin{array}{l}\text { Support for previous conceptualisations of } \\
\text { MT attributes (i.e., Jones et al., 2002), with } \\
\text { support for different development processes } \\
\text { involved across three career phases (i.e., } \\
\text { Bloom, 1985; early, middle, and later years), } \\
\text { as well as specific processes necessary to } \\
\text { maintain one's MT. }\end{array}$ \\
\hline $\begin{array}{l}\text { Performers } \\
\text { (multiple } \\
\text { environments) }\end{array}$ & $\begin{array}{l}\text { Mahoney, } \\
\text { Gucciardi, et al. } \\
(2014) \text {. }\end{array}$ & $\begin{array}{l}\text { - MT development was predicated on four higher order } \\
\text { themes: Significant others, supportive social processes, } \\
\text { critical incidents, and curiosity. } \\
\text { - MT conceptualized by nine personal characteristics: } \\
\text { Four personal forces (i.e., persistence, drive, high self- } \\
\text { expectations, and support seeking), and five personal } \\
\text { resources (i.e., forethought, social intelligence, } \\
\text { heightened awareness, self-belief, and optimistic } \\
\text { thinking). } \\
\text { - The development of personal characteristics that } \\
\text { comprise MT appear to share consistencies across } \\
\text { performance contexts. } \\
\text { - MT development viewed as a multidimensional construct. }\end{array}$ & $\begin{array}{l}\text { Whilst similar across performance contexts, } \\
\text { some difference between previous MT } \\
\text { definitions and the current study existed. } \\
\text { Furthermore, the nine MT characteristics } \\
\text { identified aligned with those reported in } \\
\text { Connaughton et al.'s (2011) review, although } \\
\text { 'control' and 'physical toughness' did not } \\
\text { emerge in the current study. }\end{array}$ \\
\hline $\begin{array}{l}\text { Coaches } \\
\text { (swimmers) }\end{array}$ & $\begin{array}{l}\text { Driska et al. } \\
(2012) \text {. }\end{array}$ & $\begin{array}{l}\text { - In terms of MT development, there were two dimensions: } \\
\text { 1. Actions of coaches: a) The coach was challenging and } \\
\text { demanding and had high expectations; b) The coach's } \\
\text { approach to training and workout planning developed } \\
\text { MT; and c) The coach developed a motivational climate } \\
\text { that fostered MT. } \\
\text { 2. Actions of swimmers: a) The swimmer prepared } \\
\text { methodically and rigorously; b) The swimmer used } \\
\text { psychological skills and cognitive strategies; and c) The } \\
\text { swimmer had experienced and overcame hardship in the } \\
\text { sport. } \\
\text { - MT development viewed as a unidimensional construct. }\end{array}$ & $\begin{array}{l}\text { While confirming eleven of thirteen } \\
\text { subcomponents of MT previously identified } \\
\text { by Jones et al. (2007), the participants } \\
\text { identified (a) "coachability", and (b) } \\
\text { "retaining psychological control on poor } \\
\text { training days" as previously unidentified } \\
\text { subcomponents of MT. }\end{array}$ \\
\hline
\end{tabular}




\begin{tabular}{|c|c|c|c|}
\hline $\begin{array}{l}\text { Participant } \\
\text { role }\end{array}$ & Study & Important findings. How to develop MT. & $\begin{array}{l}\text { Relationship with previous } \\
\text { research }\end{array}$ \\
\hline $\begin{array}{l}\text { Coaches } \\
\text { (Australian } \\
\text { football) }\end{array}$ & $\begin{array}{l}\text { Gucciardi et al. } \\
\text { (2009). }\end{array}$ & $\begin{array}{l}\text { - Five categories central to coach development of MT in } \\
\text { Australian football: Four categories to facilitate the } \\
\text { process (i.e., coach-athlete relationship, coaching } \\
\text { philosophy, training environments, and specific } \\
\text { strategies); and One to impede the process (i.e., negative } \\
\text { experiences and influences). } \\
\text { - Participants recognized the crucial role that parents play } \\
\text { in fostering childhood experiences in which a } \\
\text { "generalized form" of MT can be developed and } \\
\text { transformed into a "sport-specific form" of MT through } \\
\text { coaching methods in the football context. } \\
\text { - MT development viewed as a multidimensional construct. }\end{array}$ & $\begin{array}{l}\text { The majority of strategies and mechanisms } \\
\text { reported (e.g. encouragement, modelling, } \\
\text { and motivational climate) are consistent with } \\
\text { previous MT (e.g., Connaughton et al., 2008) } \\
\text { and talent development research (e.g., } \\
\text { Martindale, Collins, \& Daubney, 2005). }\end{array}$ \\
\hline $\begin{array}{l}\text { Coaches } \\
\text { (multiple } \\
\text { sports) }\end{array}$ & $\begin{array}{l}\text { Weinberg et al. } \\
\text { (2011). }\end{array}$ & $\begin{array}{l}\text { - Strategies to develop MT themes: tough physical practice } \\
\text { environment, positive mental environment, providing MT } \\
\text { learning opportunities. } \\
\text { - General view that MT can be developed, but coaches still } \\
\text { sought to recruit athletes that showed some MT already } \\
\text { - Higher-order MT attribute themes: Psychological skills, } \\
\text { motivation to succeed, and resilience. } \\
\text { - MT development viewed as a unidimensional construct. }\end{array}$ & $\begin{array}{l}\text { Themes tended to overlap with existing } \\
\text { literature, indicating a good deal of similarity } \\
\text { between athletes and coaches on what } \\
\text { constitutes MT. } \\
\text { Supports existing literature that highlighted } \\
\text { coaches play an important role in athletes' } \\
\text { psychological development (e.g., Gould et } \\
\text { al., 2002). }\end{array}$ \\
\hline $\begin{array}{l}\text { Performers, } \\
\text { Coaches, and } \\
\text { Support staff } \\
\text { (multiple } \\
\text { sports) }\end{array}$ & $\begin{array}{l}\text { Connaughton et } \\
\text { al. (2010). }\end{array}$ & $\begin{array}{l}\text { - MT development and maintenance occurs over four } \\
\text { distinct career phases: three developmental phases, and } \\
\text { one maintenance phase. } \\
\text { - Factors included: skill mastery, competitiveness, } \\
\text { successes (training and competition), international } \\
\text { competitive experience, education and advice, the use of } \\
\text { psychological skills, access to an understanding social } \\
\text { support network, and reflective practice. } \\
\text { - Positive and negative critical incidents were perceived by } \\
\text { participants to act as catalysts in initiating or enhancing } \\
\text { specific components of MT. } \\
\text { - MT development viewed as a multidimensional construct. }\end{array}$ & $\begin{array}{l}\text { Investigated the development and } \\
\text { maintenance of MT in relation to Jones et } \\
\text { al.'s (2007) four dimensions and } 13 \\
\text { subcomponents. }\end{array}$ \\
\hline $\begin{array}{l}\text { Coaches and } \\
\text { Support staff } \\
\text { (soccer) }\end{array}$ & $\begin{array}{l}\text { Cook et al. } \\
\text { (2014). }\end{array}$ & $\begin{array}{l}\text { - While participants had clear ideas about what constitutes } \\
\text { MT, they were less aware of how it might be } \\
\text { systematically developed. } \\
\text { - To enhance MT, coaches sought to foster in the young } \\
\text { players two key characteristics: independence and } \\
\text { resourcefulness, via a challenging but supportive learning } \\
\text { environment. } \\
\text { - MT development viewed as a multidimensional construct. }\end{array}$ & $\begin{array}{l}\text { Many of the key themes that emerged } \\
\text { closely resemble those found in other recent } \\
\text { work on perceptions of MT (Clough et al. } \\
\text { 2002; Driska et al. 2012; Jones et al. 2007; } \\
\text { Weinberg et al. 2011), that MT represents a } \\
\text { collection of positive psychological } \\
\text { variables. }\end{array}$ \\
\hline
\end{tabular}


Table 3. Assessment of retained studies against CASP (2014) Qualitative Research Checklist.

\begin{tabular}{|c|c|c|c|c|c|c|c|c|c|c|c|}
\hline Study & $\mathbf{R A}$ & QM & RD & $\mathbf{R S}$ & DC & Rel & $\mathbf{E C}$ & DA & $\mathbf{C F}$ & $\mathbf{R V}$ & Ret \\
\hline Bull et al. (2005). & $\sqrt{ }$ & $\sqrt{ }$ & $\sqrt{ }$ & $?$ & $\sqrt{ }$ & $?$ & $\sqrt{ }$ & $\sqrt{ }$ & $\sqrt{ }$ & $\sqrt{ }$ & $\sqrt{ }$ \\
\hline Butt et al. (2010). & $\sqrt{ }$ & $\sqrt{ }$ & $?$ & $?$ & $\sqrt{ }$ & $\sqrt{ }$ & $\sqrt{ }$ & $\sqrt{ }$ & $\sqrt{ }$ & $\sqrt{ }$ & $\sqrt{ }$ \\
\hline Connaughton et al. (2010). & $\sqrt{ }$ & $\sqrt{ }$ & $\sqrt{ }$ & $?$ & $\sqrt{ }$ & $?$ & $\sqrt{ }$ & $\sqrt{ }$ & $\sqrt{ }$ & $\sqrt{ }$ & $\sqrt{ }$ \\
\hline Connaughton et al. (2008). & $\sqrt{ }$ & $\sqrt{ }$ & $\sqrt{ }$ & $?$ & $\sqrt{ }$ & $?$ & $\sqrt{ }$ & $\sqrt{ }$ & $\sqrt{ }$ & $\sqrt{ }$ & $\sqrt{ }$ \\
\hline Cook et al. (2014). & $\sqrt{ }$ & $\sqrt{ }$ & $\mathrm{X}$ & $\sqrt{ }$ & $\sqrt{ }$ & $?$ & $\sqrt{ }$ & $\sqrt{ }$ & $\sqrt{ }$ & $\sqrt{ }$ & $\sqrt{ }$ \\
\hline Driska et al. (2012). & $\sqrt{ }$ & $\sqrt{ }$ & $\sqrt{ }$ & $\sqrt{ }$ & $\sqrt{ }$ & $\sqrt{ }$ & $\sqrt{ }$ & $\sqrt{ }$ & $\sqrt{ }$ & $\sqrt{ }$ & $\sqrt{ }$ \\
\hline Gucciardi et al. (2009). & $\sqrt{ }$ & $\sqrt{ }$ & $\sqrt{ }$ & $?$ & $\sqrt{ }$ & $?$ & $\sqrt{ }$ & $\sqrt{ }$ & $\sqrt{ }$ & $\sqrt{ }$ & $\sqrt{ }$ \\
\hline $\begin{array}{l}\text { Mahoney, Gucciardi, et al. } \\
\text { (2014). }\end{array}$ & $\sqrt{ }$ & $\sqrt{ }$ & $\sqrt{ }$ & $\sqrt{ }$ & $\sqrt{ }$ & $\sqrt{ }$ & $\sqrt{ }$ & $\sqrt{ }$ & $\sqrt{ }$ & $\sqrt{ }$ & $\sqrt{ }$ \\
\hline Thelwell et al. (2010). & $\sqrt{ }$ & $\sqrt{ }$ & $\sqrt{ }$ & $?$ & $\sqrt{ }$ & $\sqrt{ }$ & $?$ & $\sqrt{ }$ & $\sqrt{ }$ & $\sqrt{ }$ & $\sqrt{ }$ \\
\hline Weinberg et al. (2011). & $\sqrt{ }$ & $\sqrt{ }$ & $\mathrm{X}$ & $\sqrt{ }$ & $\sqrt{ }$ & $\sqrt{ }$ & $\sqrt{ }$ & $\sqrt{ }$ & $\sqrt{ }$ & $\sqrt{ }$ & $\sqrt{ }$ \\
\hline
\end{tabular}

Note: $\sqrt{ }=$ appropriate; ? = can't tell; $\mathrm{X}=$ inappropriate. $\mathrm{RA}=$ Research aims; $\mathrm{QM}=$ Qualitative methodology; RD = Research design; RS = Recruitment strategy; DC = Data collection; Rel = Relationships; EC = Ethical considerations; DA = Data Analysis; $\mathrm{CF}=$ Clear findings; $\mathrm{RV}=\mathrm{Research}$ value; Ret $=$ Retained. 
Table 4. Themes from primary research reports according to according to Process-Person-ContextTime (Bronfenbrenner \& Morris, 2006) constructs.

Theme
$\begin{aligned} & \text { Proximal processes (person- } \\ & \text { environment interactions) }\end{aligned}$

Study

Bull et al. (2005).

Butt et al. (2010).

Thelwell et al. (2010).

Connaughton et al. (2008).

Driska et al. (2012).

Gucciardi et al. (2009)

Weinberg et al. (2011)

Connaughton et al. (2010).

Cook et al. (2014).

Bull et al. (2005).

Person (characteristics/ attributes: forces, resources, and demands)

\section{Developing MT}

Environmental influence.

Positive but tough practice environment.

Sport process (training, competition, club),

Environmental influences (training environment, family environment).

A motivational climate that is challenging.

The coach was challenging and demanding and had high expectations, The coach's approach to training and workout planning developed MT.

Coaching philosophy, training environments (to facilitate the process).

Tough physical practice environment.

Opportunities for] skill mastery, success (training), international competitive experience, education and advice, access to an understanding social support network.

Independence, via a challenging but supportive learning environment.

Tough character,

Tough attitudes,

Tough thinking.

Butt et al. (2010).

Enhancing psych skills.

Thelwell et al. (2010).

Psychological skills training.

Connaughton et al. (2008). [Skills learnt from] the experience of critical incidents (e.g. [overcoming] setbacks, anxiety).

Mahoney, Gucciardi, et al. (2014).

[Learning from] critical incidents, and curiosity.

Personal forces: persistence, drive, high self-expectations, and support seeking, Personal resources: forethought, social intelligence, heightened awareness, self-belief, and optimistic thinking.

Driska et al. (2012).

The swimmer prepared methodically and rigorously,

The swimmer used psychological skills and cognitive strategies,

The swimmer had experienced and overcame hardship in the sport.

Gucciardi et al. (2009). Negative experiences and influences (to impede the process).

Weinberg et al. (2011). Positive mental environment.

Connaughton et al. (2010). Skill mastery, competitiveness, the use of psychological skills, and reflective practice. (Note: positive and negative critical incidents were perceived by participants to act as catalysts in initiating or enhancing specific components of MT.).

Cook et al. (2014). 


\section{Theme}

Contexts (systems include Micro, Meso, Exo, \& Macro)

Butt et al. (2010).

Thelwell et al. (2010).

Connaughton et al. (2008).

Mahoney, Gucciardi, et al. (2014).

Driska et al. (2012).

Gucciardi et al. (2009)

Weinberg et al. (2011)

Connaughton et al. (2010).

Cook et al. (2014).

\section{Developing MT}

Environmental influence.

[Relationships with] coaches (i.e., coaches' support, coaches' attributes, coaches' practices), then parents and teammates respectively.

Sporting personnel (coach, teammates, competitors, sport psychologists), Non-sporting personnel (parents, siblings, significant others),

Environmental influences (training environment, family environment, modelling, country).

Encouragement from significant others who also act as a resource of knowledge and inspiration.

Higher order themes: significant others, supportive social processes; Personal forces: support seeking.

The coach developed a motivational climate that fostered MT.

Coach-athlete relationship,

Participants recognized the crucial role that parents play in fostering childhood experiences in which a "generalized form" of MT can be developed.

Tough physical practice environment,

Positive mental environment.

International competitive experience,

Education and advice,

Access to an understanding social support network.

A challenging but supportive learning environment.
Time (daily, weekly, and career-wise)
Bull et al. (2005).

Connaughton et al. (2008).

Mahoney, Gucciardi, et al.

(2014).

Driska et al. (2012).

Gucciardi et al. (2009).

Weinberg et al. (2011)
General MT dimensions of Developmental factors, Dedication and commitment, Coping with pressure.

Challenging, rewarding, and enjoyable [motivational] climate The experience of critical incidents (e.g. setbacks, anxiety).

[Timing of] critical incidents.

The coach's approach to workout planning,

The swimmer overcame hardship in the sport.

Coaching philosophy,

Training environments,

[timing of] negative experiences and influences.

Providing learning opportunities.

Connaughton et al. (2010). [Timing of] successes (training and competition), international competitive experience, positive and negative critical incidents. 


\begin{tabular}{|c|c|c|c|}
\hline Section/topic & $\#$ & Checklist item & $\begin{array}{l}\text { Reported on } \\
\text { page \# }\end{array}$ \\
\hline \multicolumn{4}{|l|}{ TITLE } \\
\hline Title & 1 & Identify the report as a systematic review, meta-analysis/meta-study, or both. & Page 1 of 46. \\
\hline \multicolumn{4}{|l|}{ ABSTRACT } \\
\hline Structured summary & 2 & $\begin{array}{l}\text { Provide a structured summary including, as applicable: background; objectives; data sources; study eligibility } \\
\text { criteria, participants, and interventions; study appraisal and synthesis methods; results; limitations; } \\
\text { conclusions and implications of key findings; systematic review registration number. }\end{array}$ & Page 2 of 46. \\
\hline \multicolumn{4}{|l|}{ INTRODUCTION } \\
\hline Rationale & 3 & Describe the rationale for the review in the context of what is already known. & Page $3-5$ of 46. \\
\hline Objectives & 4 & $\begin{array}{l}\text { Provide an explicit statement of questions being addressed with reference to participants, interventions, } \\
\text { comparisons, outcomes, and study design (PICOS). }\end{array}$ & $\begin{array}{l}\text { N/A; aims are } \\
\text { stated on page } 5 .\end{array}$ \\
\hline \multicolumn{4}{|l|}{ METHODS } \\
\hline Protocol and registration & 5 & $\begin{array}{l}\text { Indicate if a review protocol exists, if and where it can be accessed (e.g., Web address), and, if available, } \\
\text { provide registration information including registration number. }\end{array}$ & $\begin{array}{l}\text { Not registered, but } \\
\text { meta-study process } \\
\text { detailed on p. } 5-6 .\end{array}$ \\
\hline Eligibility criteria & 6 & $\begin{array}{l}\text { Specify study characteristics (e.g., PICOS, length of follow-up) and report characteristics (e.g., years } \\
\text { considered, language, publication status) used as criteria for eligibility, giving rationale. }\end{array}$ & Page $6-7$ of 46. \\
\hline Information sources & 7 & $\begin{array}{l}\text { Describe all information sources (e.g., databases with dates of coverage, contact with study authors to identify } \\
\text { additional studies) in the search and date last searched. }\end{array}$ & Page 6 of 46. \\
\hline Search & 8 & $\begin{array}{l}\text { Present full electronic search strategy for at least one database, including any limits used, such that it could } \\
\text { be repeated. }\end{array}$ & Page 6 of 46. \\
\hline Study selection & 9 & $\begin{array}{l}\text { State the process for selecting studies (i.e., screening, eligibility, included in systematic review, and, if } \\
\text { applicable, included in the meta-analysis). }\end{array}$ & Page $6-7$ of 46. \\
\hline Data collection process & 10 & $\begin{array}{l}\text { Describe method of data extraction from reports (e.g., piloted forms, independently, in duplicate) and any } \\
\text { processes for obtaining and confirming data from investigators. }\end{array}$ & Page 7 of 46. \\
\hline Data items & 11 & $\begin{array}{l}\text { List and define all variables for which data were sought (e.g., PICOS, funding sources) and any assumptions } \\
\text { and simplifications made. }\end{array}$ & $\begin{array}{l}\text { Table } 1, \text { p. } 39-41 ; \& \\
\text { supplementary } \\
\text { material }\end{array}$ \\
\hline $\begin{array}{l}\text { Risk of bias in individual } \\
\text { studies }\end{array}$ & 12 & $\begin{array}{l}\text { Describe methods used for assessing risk of bias of individual studies (including specification of whether this } \\
\text { was done at the study or outcome level), and how this information is to be used in any data synthesis. }\end{array}$ & $\begin{array}{l}\text { Page 7-8; Table 3, } \\
\text { p. } 44 .\end{array}$ \\
\hline Summary measures & 13 & State the principal summary measures (e.g., risk ratio, difference in means). & $\mathrm{N} / \mathrm{A}$ \\
\hline Synthesis of results & 14 & $\begin{array}{l}\text { Describe the methods of handling data and combining results of studies, if done, including measures of } \\
\text { consistency }\left(e . g .,\left.\right|^{2}\right) \text { for each meta-analysis. }\end{array}$ & Page 8. \\
\hline
\end{tabular}




\begin{tabular}{|c|c|c|c|}
\hline Section/topic & $\#$ & Checklist item & $\begin{array}{l}\text { Reported on } \\
\text { page \# }\end{array}$ \\
\hline Risk of bias across studies & 15 & $\begin{array}{l}\text { Specify any assessment of risk of bias that may affect the cumulative evidence (e.g., publication bias, } \\
\text { selective reporting within studies). }\end{array}$ & $\begin{array}{l}\text { Page } 7-8 \text { of } 46 \\
\text { Table } 3 \text {, p. } 44 \text {. }\end{array}$ \\
\hline Additional analyses & 16 & $\begin{array}{l}\text { Describe methods of additional analyses (e.g., sensitivity or subgroup analyses, meta-regression), if done, } \\
\text { indicating which were pre-specified. }\end{array}$ & $\mathrm{N} / \mathrm{A}$ \\
\hline \multicolumn{4}{|l|}{ RESULTS } \\
\hline Study selection & 17 & $\begin{array}{l}\text { Give numbers of studies screened, assessed for eligibility, and included in the review, with reasons for } \\
\text { exclusions at each stage, ideally with a flow diagram. }\end{array}$ & Figure 1, p. 37. \\
\hline Study characteristics & 18 & $\begin{array}{l}\text { For each study, present characteristics for which data were extracted (e.g., study size, PICOS, follow-up } \\
\text { period) and provide the citations. }\end{array}$ & Page 10-11. \\
\hline Risk of bias within studies & 19 & Present data on risk of bias of each study and, if available, any outcome level assessment (see item 12). & Page 11-12. \\
\hline Results of individual studies & 20 & $\begin{array}{l}\text { For all outcomes considered (benefits or harms), present, for each study: (a) simple summary data for each } \\
\text { intervention group (b) effect estimates and confidence intervals, ideally with a forest plot. }\end{array}$ & Table 2, p. 42-43. \\
\hline Synthesis of results & 21 & $\begin{array}{l}\text { Present the main results of the review. If meta-analyses are done, include for each, confidence intervals and } \\
\text { measures of consistency" in accordance with the text in the Explanation and Elaboration document. }\end{array}$ & Page 13-16. \\
\hline Risk of bias across studies & 22 & Present results of any assessment of risk of bias across studies (see Item 15). & Page 11-12. \\
\hline Additional analysis & 23 & $\begin{array}{l}\text { Give results of additional analyses, if done (e.g., sensitivity or subgroup analyses, meta-regression [see Item } \\
\text { 16]). }\end{array}$ & $\begin{array}{l}\text { Page 16-21; Figure } \\
\text { 2, p. 38; Table 4, p. } \\
\text { 45-46. }\end{array}$ \\
\hline \multicolumn{4}{|l|}{ DISCUSSION } \\
\hline Summary of evidence & 24 & $\begin{array}{l}\text { Summarize the main findings including the strength of evidence for each main outcome; consider their } \\
\text { relevance to key groups (e.g., healthcare providers, users, and policy makers). }\end{array}$ & Page 21-23. \\
\hline Limitations & 25 & $\begin{array}{l}\text { Discuss limitations at study and outcome level (e.g., risk of bias), and at review-level (e.g., incomplete } \\
\text { retrieval of identified research, reporting bias). }\end{array}$ & Page 23-27. \\
\hline Conclusions & 26 & $\begin{array}{l}\text { Provide a general interpretation of the results in the context of other evidence, and implications for future } \\
\text { research. }\end{array}$ & Page 27-30. \\
\hline \multicolumn{4}{|l|}{ FUNDING } \\
\hline Funding & 27 & $\begin{array}{l}\text { Describe sources of funding for the systematic review and other support (e.g., supply of data); role of funders } \\
\text { for the systematic review. }\end{array}$ & $\begin{array}{l}\text { As listed on title } \\
\text { page. }\end{array}$ \\
\hline
\end{tabular}

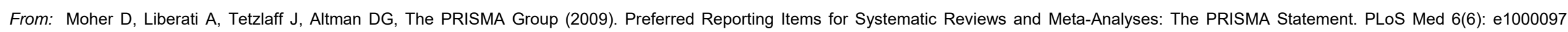
doi:10.1371/journal.pmed1000097

For more information, visit: www.prisma-statement.org. 


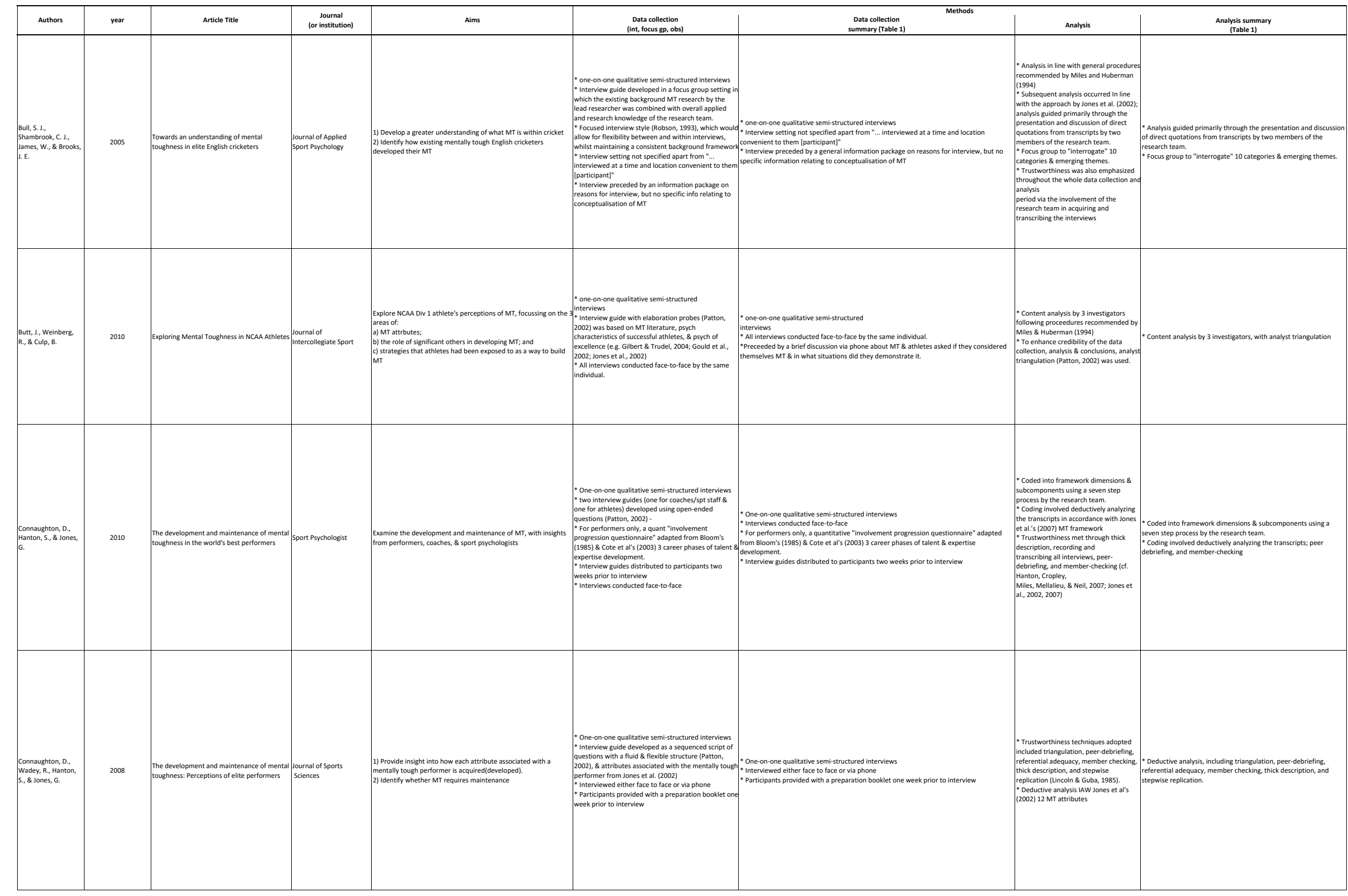




\begin{tabular}{|c|c|c|c|c|c|c|c|c|}
\hline 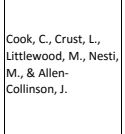 & 2014 & 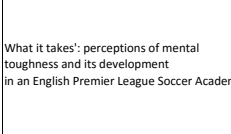 & 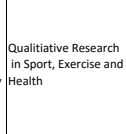 & 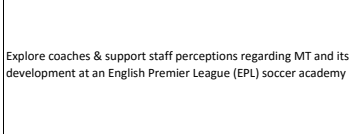 & 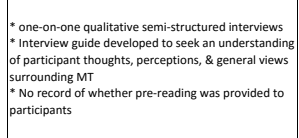 & 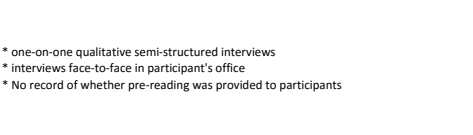 & 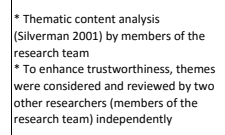 & 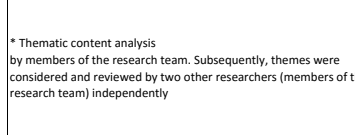 \\
\hline 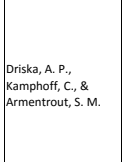 & 2012 & $\begin{array}{l}\text { Elite swimming coaches' perceptions of } \\
\text { mentat toughness }\end{array}$ & sport Psychologist & 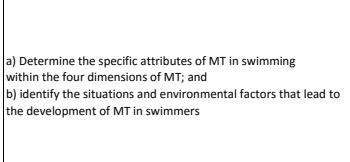 & 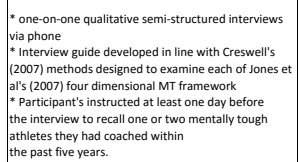 & 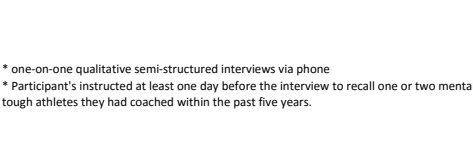 & 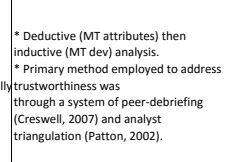 & 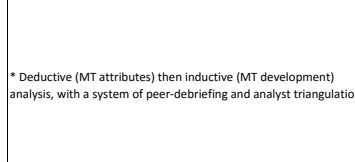 \\
\hline 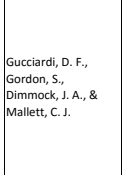 & 2009 & 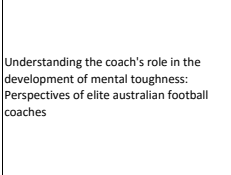 & $\begin{array}{l}\text { Dournal of Sports } \\
\text { Sciences }\end{array}$ & 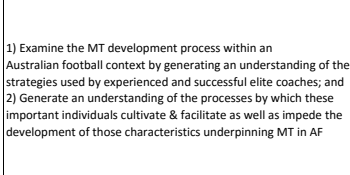 & 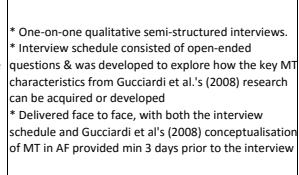 & 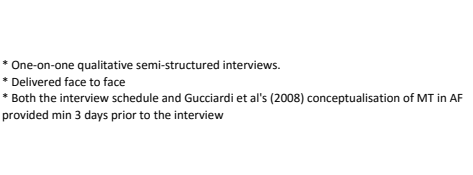 & 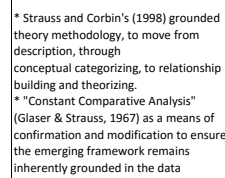 & 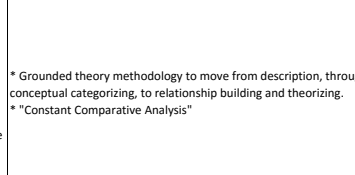 \\
\hline 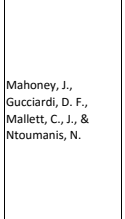 & 2014 & 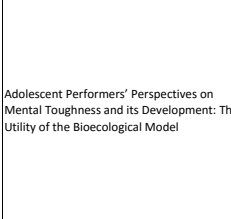 & \begin{tabular}{|l} 
The Sport \\
Peschologist
\end{tabular} & 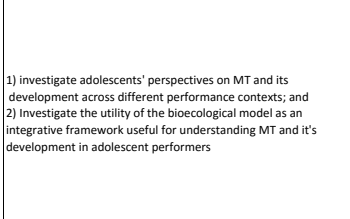 & 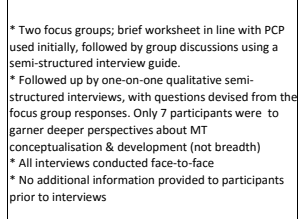 & 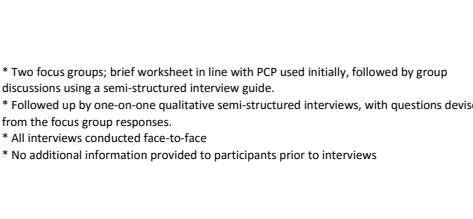 & 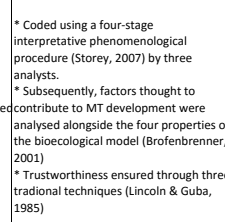 & 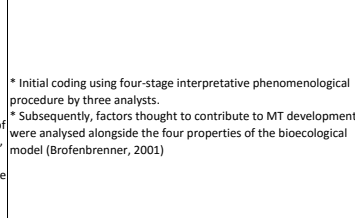 \\
\hline 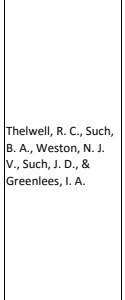 & 2010 & 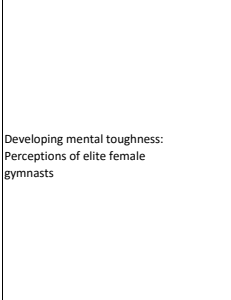 & 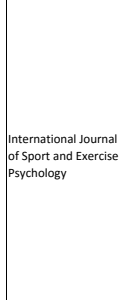 & 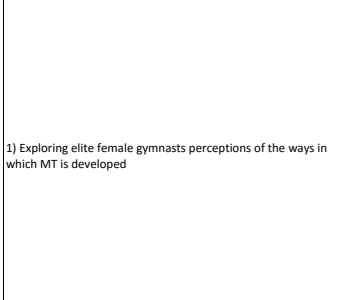 & 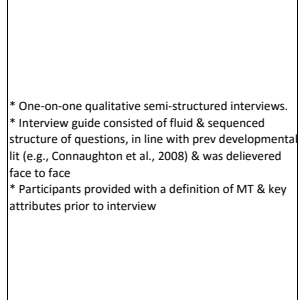 & 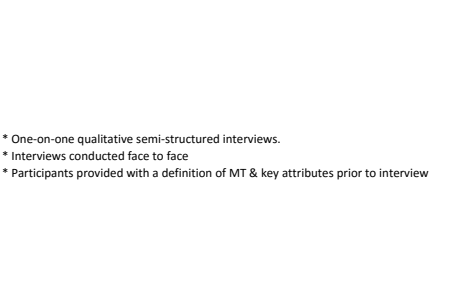 & 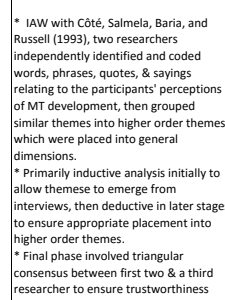 & 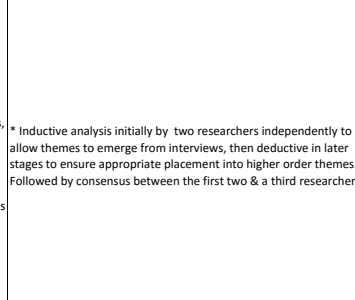 \\
\hline
\end{tabular}




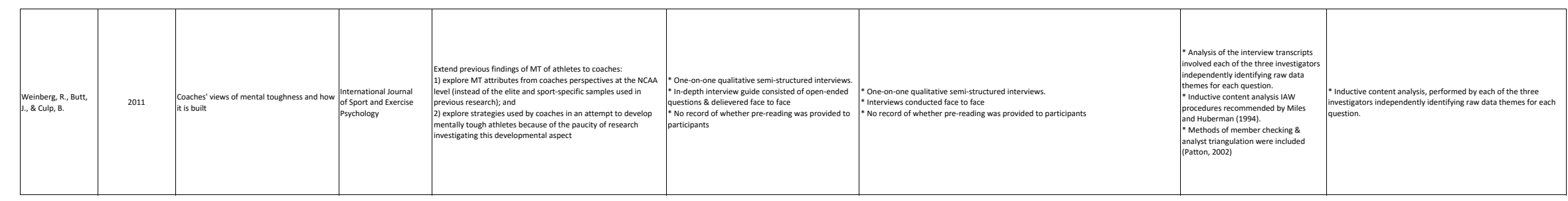




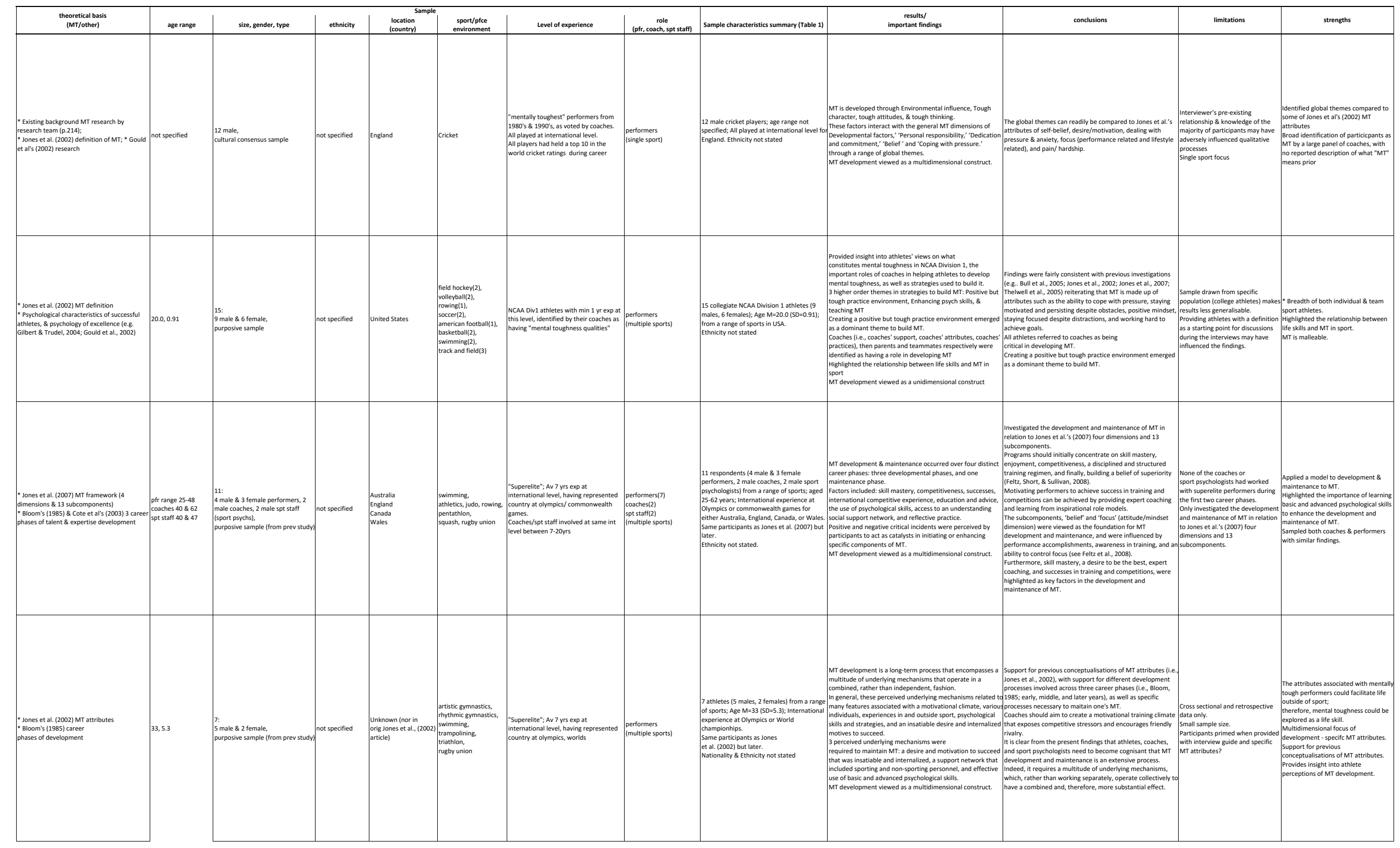




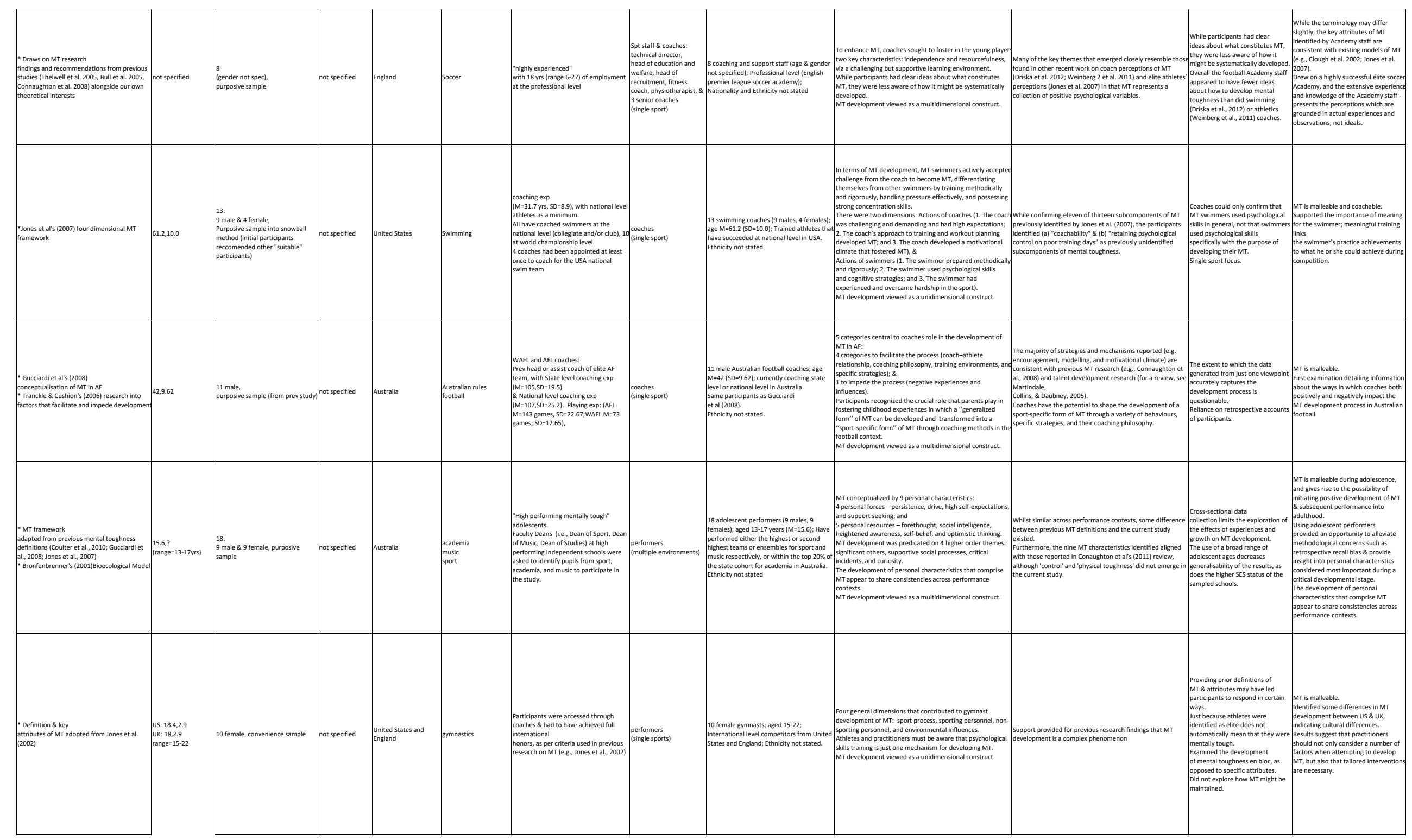




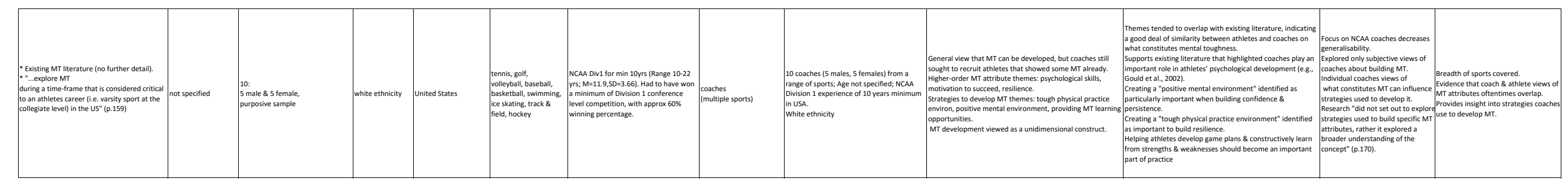

